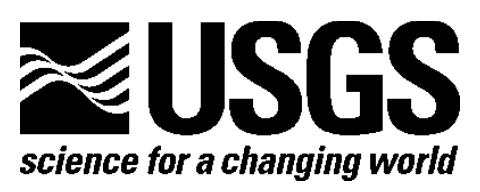

\title{
Structure of the 1906 Near-Surface Rupture Zone of the San Andreas Fault, San Francisco Peninsula Segment, Near Woodside, California
}

By C.M. Rosa, R.D. Catchings, M.J. Rymer, Karen Grove, and M.R. Goldman

Open-File Report 2016-1063

U.S. Department of the Interior

U.S. Geological Survey 


\section{U.S. Department of the Interior \\ SALLY JEWELL, Secretary}

\section{U.S. Geological Survey \\ Suzette M. Kimball, Director}

U.S. Geological Survey, Reston, Virginia: 2016

For more information on the USGS—-the Federal source for science about the Earth, its natural and living resources, natural hazards, and the environment-visit http://www.usgs.gov/ or call 1-888-ASK-USGS (1-888-275-8747).

For an overview of USGS information products, including maps, imagery, and publications, visit http://store.usgs.gov/.

Any use of trade, firm, or product names is for descriptive purposes only and does not imply endorsement by the U.S. Government.

Although this information product, for the most part, is in the public domain, it also may contain copyrighted materials as noted in the text. Permission to reproduce copyrighted items must be secured from the copyright owner.

Suggested citation:

Rosa, C.M., Catchings, R.D., Rymer, M.J., Grove, Karen, and Goldman, M.R., 2016, Structure of the 1906 nearsurface rupture zone of the San Andreas Fault, San Francisco Peninsula segment, near Woodside, California: U.S. Geological Survey Open-File Report 2016-1063, 31 p., http://dx.doi.org/10.3133/ofr20161063.

ISSN 2331-1258 (online) 


\section{Contents}

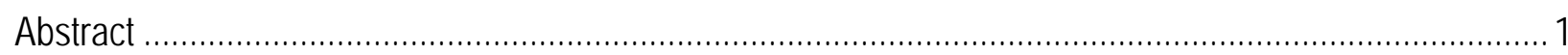

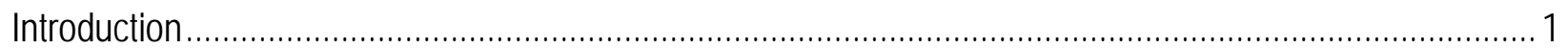

Geologic and Tectonic Setting …………

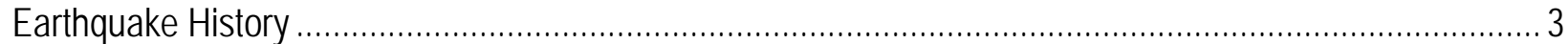

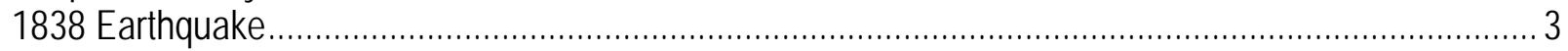

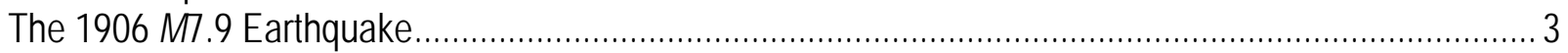

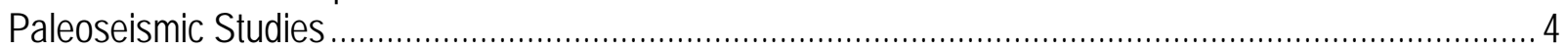

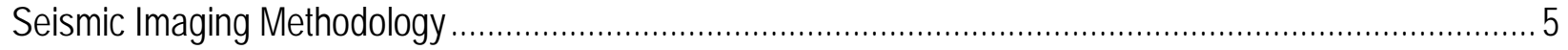

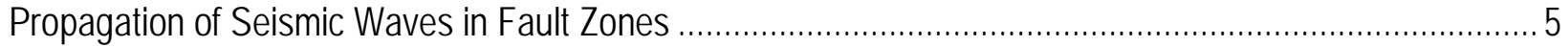

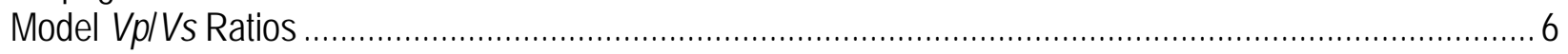

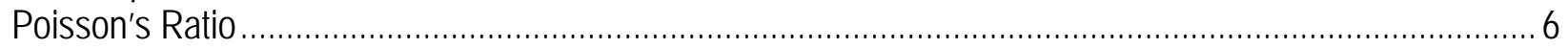

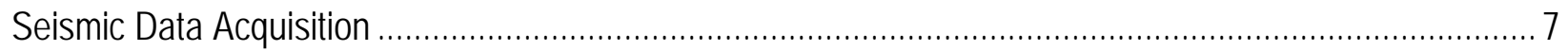

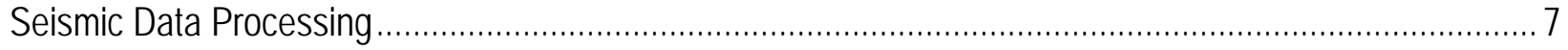

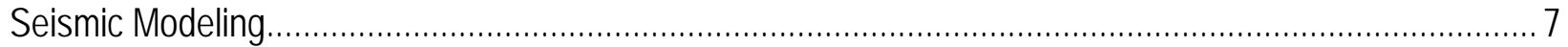

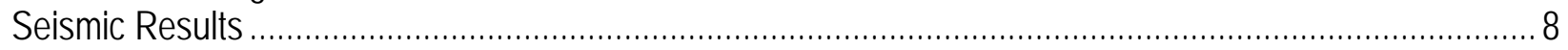

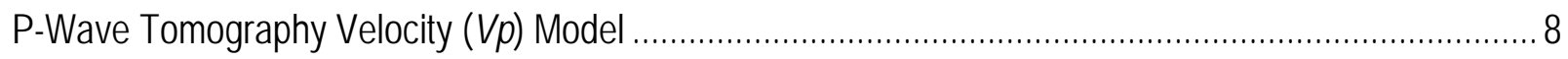

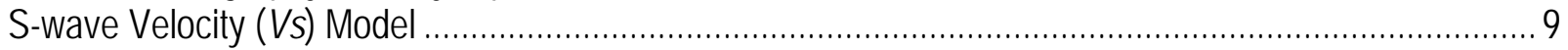

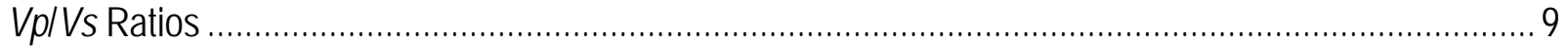

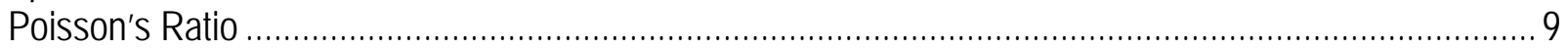

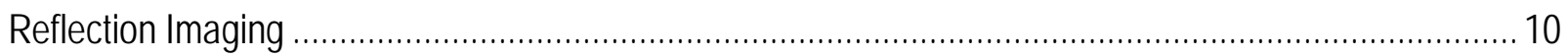

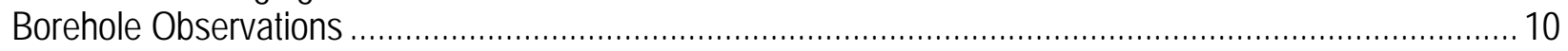

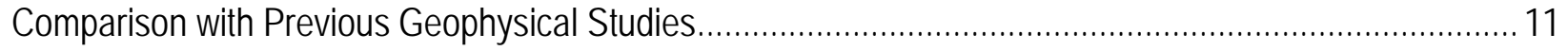

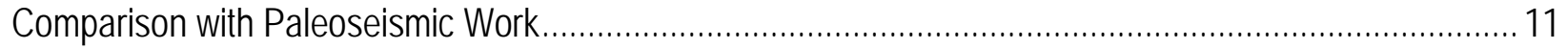

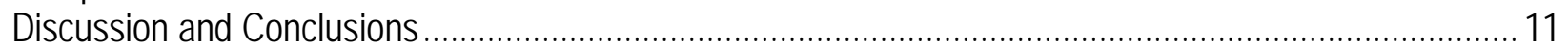

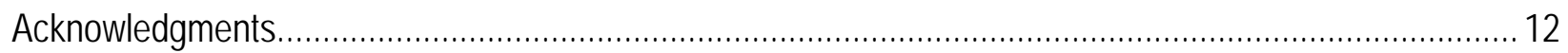

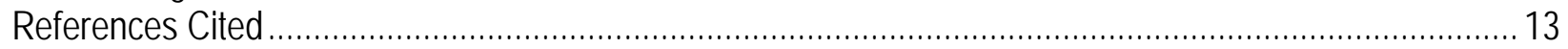

\section{Figures}

1. Annotated satellite imagery map of San Francisco Bay Area showing major faults, various cities, our study area, and estimated major historical earthquake epicenters along the San Andreas Fault.

2. Generalized geologic map of the San Francisco Peninsula and East Bay regions showing bedrock units, surficial deposits, principal faults, and cities

3. Annotated Google Earth image showing study area location and previous paleoseismic sites ...... 21

4. Lidar images showing locations of study area, seismic line, and two trenches.............................22

5. Photograph showing field site and locations of shots and geophones used in our seismic survey.....

6. Graph showing example shot gather with shot point located at southwestern end of profile at geophone \#1.

7. P-wave refraction tomography velocity model for our San Andreas Fault profile............................2 25

8. S-wave refraction tomography velocity model for the San Andreas Fault profile ...........................26

9. $\quad$ P-wave velocity/S-wave velocity (Vp/Vs) ratio image along our San Andreas Fault profile ............ 27

10. Poisson's ratio image along the San Andreas Fault profile......................................................... 28

11. Stacked reflection images without and with fault geometry interpretation for our seismic profile.... 29 
12. Stacked reflection images showing interpretations of near-surface San Andreas Fault and secondary strand at our study area with superimposed Vp model, Vs model, and P-wave velocity/S-wave velocity ratios model 30

13. Diagram showing stratigraphic sequence from borehole located at distance meter 25 of our seismic profile.

\section{Table}

1. Relevant previous paleoseismic studies on the Peninsula Segment of the San Andreas Fault...... 17 


\title{
Structure of the 1906 Near-Surface Rupture Zone of the San Andreas Fault, San Francisco Peninsula Segment, Near Woodside, California
}

\author{
By C.M. Rosa, R.D. Catchings, M.J. Rymer, Karen Grove, and M.R. Goldman
}

\begin{abstract}
High-resolution seismic-reflection and refraction images of the 1906 surface rupture zone of the San Andreas Fault near Woodside, California reveal evidence for one or more additional near-surface (within about 3 meters [m] depth) fault strands within about $25 \mathrm{~m}$ of the 1906 surface rupture. The 1906 surface rupture above the groundwater table (vadose zone) has been observed in paleoseismic trenches that coincide with our seismic profile and is seismically characterized by a discrete zone of low P-wave velocities ( $V p)$, low S-wave velocities $(V s)$, high $V p / V s$ ratios, and high Poisson's ratios. A second nearsurface fault strand, located about $17 \mathrm{~m}$ to the southwest of the 1906 surface rupture, is inferred by similar seismic anomalies. Between these two near-surface fault strands and below $5 \mathrm{~m}$ depth, we observed a near-vertical fault strand characterized by a zone of high $V p$, low $V s$, high $V p / V s$ ratios, and high Poisson's ratios on refraction tomography images and near-vertical diffractions on seismicreflection images. This prominent subsurface zone of seismic anomalies is laterally offset from the 1906 surface rupture by about $8 \mathrm{~m}$ and likely represents the active main (long-term) strand of the San Andreas Fault at 5 to $10 \mathrm{~m}$ depth. Geometries of the near-surface and subsurface (about 5 to $10 \mathrm{~m}$ depth) fault zone suggest that the 1906 surface rupture dips southwestward to join the main strand of the San Andreas Fault at about 5 to $10 \mathrm{~m}$ below the surface. The 1906 surface rupture forms a prominent groundwater barrier in the upper 3 to $5 \mathrm{~m}$, but our interpreted secondary near-surface fault strand to the southwest forms a weaker barrier, suggesting that there has been less or less-recent near-surface slip on that strand. At about $6 \mathrm{~m}$ depth, the main strand of the San Andreas Fault consists of water-saturated blue clay (collected from a hand-augered borehole), which is similar to deeply weathered serpentinite observed within the main strand of the San Andreas Fault at nearby sites. Multiple fault strands in the area of the 1906 surface rupture may account for variations in geologic slip rates calculated from several paleoseismic sites along the Peninsula segment of the San Andreas Fault.
\end{abstract}

\section{Introduction}

The San Andreas Fault (SAF) is a 1,300-kilometer (km)-long continental transform fault that extends through much of California (fig. 1A; Wallace, 1990). Cumulative right-lateral displacement along the SAF has resulted in at least $300 \mathrm{~km}$ of offset and juxtaposition of distinctively different basement rock types (Irwin, 1990). For example, in central and northern California, oceanic CretaceousJurassic Franciscan Complex rocks are northeast of the SAF and contact Mesozoic continental plutonic and older metamorphic rocks of the Salinian terane to the southwest (fig.2; Irwin, 1990). However, there are local exceptions to this generalization (Rymer and others, 2006). In our study area on the San Francisco Peninsula, the Pilarcitos Fault (west of the SAF) is the bedrock boundary, and Franciscan 
Complex rocks are exposed on both sides of the active strand of the SAF (fig. 2; Parsons and Zoback, 1997).

In the San Francisco Bay Area, the San Andreas Fault System is about an 80-km-wide zone composed of four principal fault strands: the San Gregorio Fault, the SAF, the Rodgers Creek-Hayward Fault, and the Green Valley-Concord-Calaveras Fault (fig. 1B; Savage and others, 1999). These principal faults and many other smaller faults accommodate about 40 millimeters per year (mm/yr) of right-lateral shear between the Pacific and Sierra Nevada-Great Valley Plates (fig. 1; Parsons and Zoback, 1997). In this report, we focus on the Peninsula segment of the SAF, which accommodates 14.5 to $23 \mathrm{~mm} / \mathrm{yr}$ of long-term slip and does not display evidence of creep (Kelson and others, 1996; Savage and others, 1999; WGCEP, 2008). The Peninsula segment of the SAF is about $85 \mathrm{~km}$ long and extends from offshore of the Golden Gate near the epicenter of the 1906 earthquake, southward to near Los Gatos at the north end of the Loma Prieta aftershock zone (fig. 1B; Hall and others, 1999; WGCEP, 2003).

The Peninsula segment of the SAF poses a significant hazard for the San Francisco Bay Area, yet, there is much uncertainty about the slip rate and history of earthquakes prior to the April 18, 1906 M7.9 event (table 1). Much of the uncertainty may result from paleoseismic studies that excluded slip on fault strands other than the 1906 surface rupture.

To better understand the near-surface fault geometry of the most recently active trace of the SAF, we conducted a 60-m-long, shallow-depth, high-resolution seismic-imaging survey across the 1906 surface rupture zone near the Filoli Center in Woodside, California. Our study area is about $1.2 \mathrm{~km}$ southeast of Upper Crystal Springs Reservoir (fig. 1b), on the Peninsula segment of the SAF (figs. 1b and 3). We chose this study area because of its proximity to previous and ongoing paleoseismic investigations (figs. 3 and 4). Our seismic images show details of the subsurface structure of the SAF that can aid paleoseismological studies in identifying all near-surface rupture zones within about 30 meters (m) of the 1906 surface rupture. By accounting for slip on all near-surface ruptures, average earthquake recurrence intervals and slip rates for the Peninsula segment of the SAF may be more accurately determined.

\section{Geologic and Tectonic Setting}

South of San Francisco, the SAF passes through Franciscan Complex rocks, such that Franciscan rocks are located on both sides of the fault (fig. 2; Pampeyan, 1994; Brabb and others, 2000). The Franciscan Complex, the oldest unit in the South San Francisco Bay region, consists of CretaceousJurassic-aged rocks that are weakly to strongly metamorphosed and locally consists of sandstone, greenstone, serpentinite, chert, schist, and limestone in a sheared mudstone matrix mélange (fig. 2; Pampeyan, 1994; Brabb and others, 2000). In our immediate study area, this geologic complexity strongly affects what can be seismically imaged with conventional seismic imaging techniques (Catchings and others, 2014). Quaternary deposits at our study area include landslide deposits, ravine fill, and debris-flow material, along with stream deposits, alluvium, and local lake deposits (Page, 1981; Pampeyan, 1994). Sedimentary deposits adjacent to our study area are Pliocene to Pleistocene in age and include the nonmarine Santa Clara Formation, which consists of conglomerate, sandstone, and mudstone (Brabb and others, 2000). Pleistocene coarse-grained alluvial fan and fluvial terrace deposits that contain poorly consolidated gravel, sand, and silt are also found in our study area (Brabb and others, 2000).

Locally, the SAF trends along the east edge of the Santa Cruz Mountains, forming a linear valley that has been flooded by the Crystal Springs and San Andreas Reservoirs (fig. 3). In addition to the strike-slip component of displacement, the 1906 surface rupture of the SAF here includes west-side-up 
vertical displacement, which has resulted in a 5-10-m-high, northeast-facing scarp along the foot of the mountains (Zachariasen and others, 2011).

In our study area, Spring Creek drains an area of about 3 square kilometers $\left(\mathrm{km}^{2}\right)$ on the northeast margin of the northern Santa Cruz Mountains and has deposited sediments and an alluvial fan across the SAF during the Holocene (fig. 4). Eocene Butano Sandstone and nonmarine units of the Pliocene-Pleistocene Santa Clara Formation underlie the Spring Creek Basin. Immediately to the southeast of our study area, Spring Creek breaches the scarp of the 1906 surface rupture near the head of an alluvial fan (fig. 4). Trenching at our seismic line site exposed fluvial channel and overbank deposits overlying a dark-gray clayey deposit that contains weathered pebble-sized clasts, as well as fault ruptures from past events (table 1; Zachariasen and others, 2011).

\section{Earthquake History}

The SAF accommodates more than half of the dextral slip partitioned across the San Francisco Bay Area, and three of the four historical largest-magnitude $(M \geq 6.7)$ earthquakes $(1838,1906$, and 1989) have occurred on or near the SAF (fig. 1B; WGCEP, 2003). Field and others (2015) estimate that by 2043, there is a mean probability of 72 percent of at least one $M \geq 6.7$ earthquake occurring in the San Francisco Bay Area and a mean probability of 33 percent for this magnitude event occurring on the northern SAF. The northern SAF has been divided into four main sections - the Offshore, North Coast, Peninsula, and Santa Cruz Mountains sections (fig. 1B; WGCEP, 2003; 2008). Of these four sections, the Peninsula section has a mean probability of 9 percent for an $M \geq 6.7$ event (WGCEP, 2013). Although this value is lower than postulated for other sections of the SAF and faults further inland (WGCEP, 2013), it is important to study due to its proximity to infrastructure and a large populous. The Peninsula section last ruptured in 1906 and is also thought to have ruptured during a smaller, 1838 event (estimated at M6.8-7.4), although there is no clear evidence placing the 1838 event on the SAF (WGCEP, 2003).

\section{Earthquake}

The paleoearthquake record for the Peninsula segment of the SAF has yielded inconsistencies about the age and extent of the penultimate (second to last) event. Toppozada and Borchardt (1998) and Bakun (1999) modeled intensity data in the region and concluded that the June 1838 earthquake was located somewhere on the San Francisco Peninsula (fig. 1B). On the basis of newspaper articles and other evidence of damage and shaking in Monterey and San Francisco following the 1838 event, Toppozada and Borchardt (1998) suggested the 1838 event ruptured a 140-km-long segment of the SAF rather than a previously assumed shorter 60-km-long rupture segment. Longer rupture length implies the 1838 event had a magnitude on the order of $\sim$ M7.5. Bakun (1999), however, estimated a magnitude of M6.8 for the 1838 event based on the Modified Mercalli Intensity Scale (MMI) ratings at various locations around the Bay Area, and he further estimated that the epicenter of the 1838 earthquake was near Woodside (fig. 1). Current earthquake hazard assessments for the Bay Area assume that the 1838 event occurred on the Peninsula segment of the SAF, although direct paleoseismic evidence is inconclusive (table 1).

\section{The 1906 M7.9 Earthquake}

According to Hall and others (2001), the Peninsula segment of the SAF has been active throughout the Holocene, with surface ruptures along multiple fault traces. The most recent surface rupture occurred during the April 18, 1906 M7.9 San Francisco earthquake (Lawson, 1908; Parsons and Zoback, 1997), which ruptured the surface for about $470 \mathrm{~km}$ from near San Juan Bautista in the south to 
the Mendocino Triple Junction in the north (fig. 1A; Prentice, 1999). Rupture occurred on all four Bay Area segments of the SAF (fig. 1b; WGCEP, 2003; 2008). On the Peninsula segment, Hall (1984) reported about $3 \mathrm{~m}$ of right-lateral offset based on paleoseismic evidence observed near Crystal Springs Reservoir in San Mateo County, where 90 percent of the motion was confined to a 30-m-wide zone (fig. $1 B$ ). South of Woodside in Portola Valley (fig. 1b), lateral offset reportedly decreased significantly and was probably about $1.2 \mathrm{~m}$ (Hall and others, 2001).

\section{Paleoseismic Studies}

Although there have been numerous paleoseismic studies on the SAF, minimal work has been done on the Peninsula segment and there are several conflicting results (table 1; fig. 3; Hall and others, 1999; Baldwin and others, 2006; Prentice and Moreno, 2007; Baldwin and Prentice, 2008; Prentice and others, 2008; Zachariasen and others, 2011).

Hall and others (1999) excavated many fault-perpendicular and fault-parallel trenches at the Filoli site (fig. 3), where late Holocene alluvial fan materials were deposited over the fault. They calculated an average late Holocene slip rate of $17 \pm 4 \mathrm{~mm} / \mathrm{yr}$ for the Peninsula segment of the SAF (table 1). Recently, however, Zachariasen and others (2010) reinterpreted the data of Hall and others (1999) and suggested there may not be direct evidence that a pre-1906 event occurred at this site in the past few hundred years.

In a more recent paleoseismic investigation along the Peninsula segment, about $10 \mathrm{~km}$ northwest of our study area at the northern end of Lower Crystal Springs Reservoir, Prentice and Moreno (2007) identified the 1906 rupture and one previous event (table 1; fig. 3) estimated to have occurred between A.D. 890 and 1260. A second trench located at Lower Crystal Springs Reservoir showed evidence for the 1906 earthquake, but no prior events were identified within their 3-m-deep exposure (table 1; fig. 3; Prentice and others, 2008). Prentice and others (2008) offered several reasons to explain these observations, including (1) high sedimentation rates at the site during the late 19th and 20th centuries may have masked the 1838 event horizon; (2) the penultimate earthquake may have occurred prior to the 19th century; and (3) there may have been a depositional gap between faulted and unfaulted sediments, implying that multiple earthquakes are represented in the event horizon.

From a trench at Portola Valley Town Center, about $16 \mathrm{~km}$ southeast of the Filoli site, Baldwin and others (2006) and Baldwin and Prentice (2008) interpreted evidence for the presence of at least three, and possibly four, pre-1906 events in about 1,000 years (table 1; fig. 3). Based on radiocarbon dating, events are interpreted to have occurred at (1) A.D. 1030 to 1490, (2) A.D. 1260 to 1490, and (3) A.D. 1906 (Baldwin and Prentice, 2008). The data allow for a possible alternative interpretation of the second event as two events (A.D. 1260 to 1490 and A.D. 1410 to 1640) (Baldwin and Prentice, 2008). Although some ages for these events are consistent with results at other sites, evidence for the 1838 event was not found at Portola Valley Town Center.

In our study area at Filoli, 1.2 km southeast of Crystal Springs Reservoir (fig. 3), Zachariasen and others (2011) excavated two cross-fault trenches that exposed fluvial deposits ( 1,000 years old) overlying an older ( 3,100 years old) clay-rich unit. Zachariasen and others (2011) found evidence for only two events that occurred during the past 1,000 years: one in 1906, and the other $600-1,000$ years ago (table 1). They found no direct evidence that the 1838 earthquake caused surface rupture on the 1906 surface rupture of the SAF (table 1). This record of two earthquakes in 1,000 years is similar to the paleoseismic record of Prentice and others (2008) at Crystal Springs Reservoir to the northwest (fig. 3). Conversely, evidence for three to four events in 1,000 years was observed at the Portola Valley Town Center site to the southeast (fig. 3).

Although there have been multiple paleoseismic investigations along the Peninsula segment of the SAF, conflicting results bring into question the completeness of earthquake records at various sites 
and whether all near-surface strands of the SAF, other than the 1906 surface rupture, have been investigated. Further paleoseismic research on the Peninsula segment of the SAF, including investigations on potential auxiliary strands, is needed to accurately determine slip history and average earthquake recurrence intervals. In this study, we used seismic imaging methods to examine the possibility of unidentified near-surface fault strands not included in other paleoseismic studies.

\section{Seismic Imaging Methodology}

To better understand the near-surface geometry of the Peninsula segment of the SAF, we used combined high-resolution seismic refraction tomography and reflection methods. Our methodology, described by Catchings and others (2014), provides multiple independent measures of fault structure and can be used to locate faults that may not be apparent at the surface. Near-surface fault-zone imaging is important because rupture, strong ground motions, and paleoseismic investigations occur in the near surface and geophysical methods can locate previously unknown faults. Seismic-reflection imaging is a useful and proven method to image subsurface fault zones under favorable geologic conditions, particularly where faults vertically offset sub-horizontally layered strata, where faults bisect rocks with marked differences in reflectivity, and (or) where faults are inclined at low angles relative to the surface. However, our study area has less than ideal geologic conditions, where lithologic variations, groundwater saturation, faulting, and fracturing have created geologic complexity in the upper few tens of meters that make conventional near-surface seismic imaging of fault zones difficult (Catchings and others, 2014). Therefore, in this study, we used multiple seismic methods to image the 1906 surface rupture zone of the SAF. Below, we provide some brief background information to better understand our methodology.

\section{Propagation of Seismic Waves in Fault Zones}

Multiple features of the shallow subsurface affect seismic wave propagation in and around fault zones. In particular, near-surface P- and S-wave propagation are greatly affected by the extent of shearing, rock damage, and variations in groundwater saturation. These factors help us to interpret fault zones from seismic images.

Shearing can damage host rocks as far as hundreds of meters from the causative fault (Flinn, 1977; Wallace and Morris, 1986; Wilson and others, 2003; Sibson, 2003; Chester and others, 2005) by significantly reducing the bulk and shear moduli in the damaged rock (Chester and Logan, 1986; Gupta and Bergstrom, 1998), especially if there is a high clay content (Wu, 1978; Han and others, 1986). As a result, $\mathrm{P}$ - and S-wave velocities (Vp and Vs, respectively) are typically lower in fault zones than in the adjacent host rocks (Mayer-Rosa, 1973; Healy and Peake, 1975; Aki and Lee, 1976; Wang and others, 1978; Spudich and Angstman, 1980; Mooney and Luetgert, 1982; Thurber, 1983; Mooney and Ginzburg, 1986; Li and Leary, 1990; Catchings and others, 2002, 2009, 2013, 2014). On seismic velocity images, zones of low $V s$ within nearly all velocity ranges characterize faults, but empirical studies show that low-velocity zones are usually observed only when $V p$ is greater than 2,500 meters per second (m/s) (Catchings and others, 2014).

Groundwater saturation within subsurface materials, including fault zones, significantly increases $V p$ relative to unsaturated or partially saturated materials. Thus, high levels of groundwater saturation, particularly in the near surface, can counteract decreases in $V p$ caused by faulting. As a result, $V p$ in near-surface saturated fault zones can be relatively high, and a $V p$ low-velocity zone will not be observed. However, at greater depths, where rocks are more consolidated (usually Vp > 2,500 $\mathrm{m} / \mathrm{s}$ ), reductions in the bulk and shear moduli caused by faulting result in a prominent low-velocity zone around the fault (Catchings and others, 2014). 
Because faults are usually barriers to groundwater flow (Tolman 1937; Dutcher and Garrett, 1963; Proctor, 1968; Clark, 1984; Wallace and Morris, 1986; Bredehoeft and others, 1992; Haneberg, 1995; Catchings and others, 1999, 2006, 2009, 2013, 2014), groundwater often collects around nearsurface faults and, depending on the level of saturation, $V p$ in the near-surface fault zone can be similar or higher in velocity than host rocks (Catchings and others, 2014). However, groundwater saturation has little effect on Vs, such that faults will constitute Vs low-velocity zones, even where there are high levels of groundwater saturation. Thus, the ratio of $V p$ to $V s$ is typically high (5 to 10) in near-surface saturated fault zones, and high $V p / V s$ ratios, particularly when near-vertically oriented, can be a strong indicator of the presence of faults (Catchings and others, 2014).

These near-surface properties make the refraction tomography method particularly well suited for $V p$ and $V s$ imaging of near-surface fault zones. In addition to high $V p / V s$ ratios, fault zones are also typically characterized by abrupt lateral variations in the depth to the top of groundwater because most faults form groundwater barriers. As a result, the depth to groundwater is typically lower across the fault zone in the downslope direction of groundwater flow. Multiple empirical tomographic imaging studies have shown that the depth to the top of groundwater correlates with a $V p$ of about 1,500 m/s (Catchings and others, 1999, 2009, 2013, 2014). Thus, abrupt downslope variations in the depth to the 1,500 m/s velocity contour (top of groundwater) can also be used to infer subsurface faults.

\section{Model Vp/Vs Ratios}

In our study, $V p$ and $V s$ refraction tomography models were developed independently using first arrivals from co-located sources and receivers. Because both velocity models are well constrained with identical parameters, we used these models to develop a tomography model of $V p / V s$ ratios by dividing $V p$ by $V s$ at each grid point of the velocity models. Because $V p / V s$ ratios are calculated on the basis of both P-wave and S-wave data and because P-waves typically propagate to shallower depths than Swaves for a given source-receiver offset, we calculated the $V p / V s$ ratio model only to the maximum depth of the $V p$ model.

\section{Poisson's Ratio}

We calculated Poisson's ratio, which is a measure of the amount of extension in one direction to the amount of compression in a perpendicular direction, using our modeled $V p$ and $V s$ within the following equation derived by Thomsen (1990):

$$
v=\frac{\mathrm{E}}{2 \mu}-1=\frac{(3 \mathrm{~K}-2 \mu)}{(6 \mathrm{~K}+2 \mu)}=\frac{\left(\left[\frac{V p}{V S}\right] 2-2\right)}{2\left(\left[\frac{V p}{V S}\right] 2-2\right)}
$$

where $v$ is Poisson's Ratio,

$\mu$ is shear modulus (ratio of stress to strain),

E is Young's modulus (measure of stiffness of an elastic material),

$\mathrm{K}$ is bulk modulus (measure of material's resistance to uniform compression),

$V p$ is $\mathrm{P}$-wave velocity, and

Vs is S-wave velocity. 
Poisson's ratio can vary from 0 to 0.5 for most crustal materials, whereby 0.5 is typically the Poisson's ratio of a fluid. Poisson's ratio can provide useful information about shallow groundwater saturation because large increases in $V p$ and Poisson's ratio can be characteristic of water-saturated sediments and rocks below the vadose zone (Catchings and others, 2013). Empirical studies near our study area have shown that a Poisson's ratio of about 0.44 in the near-surface correlates with the top of groundwater (Catchings and others, 2006, 2013, 2014). High values of Vp and Poisson's ratio can also be caused by groundwater that ponds adjacent to and within faults (Catchings and others, 2014).

\section{Seismic Data Acquisition}

In June 2012, we acquired a 60-m-long, combined high-resolution seismic-refraction and reflection survey near the Filoli Center in Woodside, California, south of Upper Crystal Springs Reservoir (fig. 4). The profile was oriented NE-SW, approximately 60 degrees to the trend of the SAF and centered on the 1906 surface rupture (fig. 4). Our survey length and location were largely dictated by the terms of our permit with the property owner and the known 1906 surface rupture location. Thus, our seismic-profile length and orientation were constrained to the 60-m-long profile shown in figure 4.

Seismic sources were spaced laterally every $1 \mathrm{~m}$ (fig. 5) to produce high-density P- and S-wave data. The P-wave data were recorded on a 60-channel Geometrics Strataview ${ }^{\mathrm{TM}} \mathrm{RX}-60$ seismograph attached to $40-\mathrm{Hz}$, single-element, Mark Products L-40A ${ }^{\mathrm{TM}}$ geophones. Geophones were co-located with each shot location. Each recording site and shot was measured using a meter tape and flagged to obtain proper spacing. Coordinates for each geophone and shot were determined using a handheld Trimble Geox (GeoExplorer) GPS. P-waves were generated using vertical 4.5-kg hammer impacts on a steel plate located on the ground surface. S-waves were generated by horizontally striking an aluminum block (with cleats to add shear to the surface) using a 4.5-kg hammer. Approximately $2 \mathrm{~s}$ of data were recorded for each shot.

A sample shot gather is shown in figure 6 . We used 60 shot locations to produced 60 shot gathers, resulting in approximately 3,600 first arrivals to generate the velocity models. We also used the same 3,600 seismic traces to generate reflection images. During acquisition, geophones remained fixed while each type of seismic source (P-wave and S-wave) was used along the profile. This acquisition layout allowed both refraction tomography data and reflection data to be generated from the same dataset.

\section{Seismic Data Processing}

The seismic data were initially processed with an interactive seismic processing package (ProMAX ${ }^{\mathrm{TM}}$ ), and first-arrivals were measured to within about 1 millisecond. First arrivals were then used to calculate seismic velocities using the code from Hole (1992). Reflection data were processed (also on ProMAX ${ }^{\mathrm{TM}}$ ) using only P-wave reflections, and several editing steps were taken to maximize the seismic signal.

\section{Seismic Modeling}

To develop velocity models using the P- and S-wave first-arrival refraction data, we used a modified version of Hole's (1992) algorithm, which uses two-dimensional or three-dimensional raytracing of P- and (or) S-wave data to model first-arrival travel times through a gridded starting velocity model. This approach maps velocity contrasts in the Earth’s subsurface. Observed and calculated first-arrival travel times are compared until a reasonable fit is obtained for all arrivals from all sources (Hole, 1992). The model is continuously adjusted by the user throughout the process to improve 
equivalence between observed and computed times until a realistic model is produced that agrees with known travel-time data gathered from the study.

In general, the refraction tomography method uses mathematical inverse methods to develop statistically optimal solutions for ray paths directly from first-arrival data (Sleep and Fujita, 1997). These models are composed of a grid of specified velocities, with interpolations in between (Hole, 1992; Sleep and Fujita, 1997). This grid allows the subsurface to be divided into cells, and raypaths through these cells are computed to derive model velocities (Sleep and Fujita, 1997). Generally, the greater the number of raypaths that travel through a given cell, the better the final model solution will be. Model regions that include an insufficient number of rays can lead to computational artifacts in the form of single-cell high-amplitude anomalies (Hole, 1992; Sleep and Fujita, 1997; Kissling and others, 2001).

Velocity models produced in this study were parameterized using a 1-m by 1-m grid to parameterize Earth structure. Grid parameters were determined by acquisition parameters, including the seismic line length, geophone and shot spacing, and maximum reasonable depth $(\sim 30 \mathrm{~m})$ that the model could be resolved with accurate velocities. We created multiple starting velocity models to invert the data, and for each starting velocity model, we used 40 successive iterations. We used successively less smoothing of the velocity structure in successive iterations based on misfits between observed and calculated arrival times. Regardless of the starting model used, each inversion yielded similar final velocity models, suggesting that the velocity structure is well resolved. When deciding which final models were best, 20-30 iterations for each model were ranked by image resolution and clarity.

$\mathrm{P}$-wave seismic-reflection images require both P-wave reflection data and a suitable velocity model. We processed the reflection data with ProMAX ${ }^{\mathrm{TM}}$ using the following steps: geometry installation, trace editing, bandpass filtering, amplitude correction, timing corrections, velocity analysis, moveout correction, muting, stacking, and depth conversion.

\section{Seismic Results}

This study produced multiple tomographic models and a seismic-reflection image detailing shallow subsurface structure of the Peninsula segment of the SAF at the study area, as discussed in the following sections.

\section{P-Wave Tomography Velocity (Vp) Model}

P-wave velocities ( $V p$ ) range from about $400 \mathrm{~m} / \mathrm{s}$ at the surface to more than 3,000 m/s at depths of about $20 \mathrm{~m}$ below the ground surface (fig. 7). The lowest $V p$ values ( $\sim 00 \mathrm{~m} / \mathrm{s}$ ) occur at the surface between distance meters 25 to 30 and 45 to 60, but there are also discrete zones of relatively low $V p$ ( $\sim 500 \mathrm{~m} / \mathrm{s}$ ) at distance meters 18, 21 to 33, and 37 to 39. Based on observations from a paleoseismic study (Zachariasen and others, 2011) that was located between meters 34 and 42 of our seismic profile, our model shows that the near-surface low- $V p(\sim 500 \mathrm{~m} / \mathrm{s})$ zone between meters 37 and 39 correlates with the 1906 surface rupture. Another near-surface zone of relatively low $V p(\sim 500 \mathrm{~m} / \mathrm{s})$ between meters 21 to 33 may also correlate with a secondary fault strand. We interpret the relatively low $V p$ between meters 45 and 50 to also coincide with a thicker accumulation of sediments and a possible fault strand (fig. 7).

The 1,500 m/s velocity contour, which been shown to correlate with the depth to the top of groundwater (Catchings and others, 2000, 2013, 2014), can also provide information about the presence of faults. In our $V p$ seismic image (fig. 7), the $1,500 \mathrm{~m} / \mathrm{s}$ velocity contour shows that the top of static groundwater is about 3-7 m below the ground surface along most of the seismic profile (fig. 7). This is consistent with the southwestern end of the paleoseismic trench by Zachariasen and others (2011), even 
though seismic and trench data were not acquired at the same time (fig. 7). Our seismic data show that the top of groundwater ( $1,500 \mathrm{~m} / \mathrm{s}$ contour) is vertically offset by $3 \mathrm{~m}$ near distance meter 38 , which is below the northeastern side of the trench (fig. 7). This offset shows that the 1906 surface rupture forms a groundwater barrier, whereby groundwater that flows from higher elevations on the southwest is impeded by the fault. There is also a gradual $(\sim 1 \mathrm{~m})$ offset in the 1,500 m/s velocity contour near meter 21 (down to the northeast) and two abrupt offsets ( $\sim 3 \mathrm{~m})$ near meters 7 and 52; however, the abrupt offsets in the 1,500 m/s velocity contour near meters 7 and 52 may be related to edge effects of the velocity model. Groundwater (1,500 m/s contour) appears shallowest between meters 21 and 38, consistent with two near-surface $(\sim 3 \mathrm{~m})$ strands of the SAF that are groundwater barriers. Distance meters 21 and 38 are also the approximate locations of the low- $V p$ zones discussed above.

\section{S-wave Velocity (Vs) Model}

Along our seismic profile, S-wave velocities (Vs) range from about $220 \mathrm{~m} / \mathrm{s}$ at the surface to about $800 \mathrm{~m} / \mathrm{s}$ at about $20 \mathrm{~m}$ below the ground surface (fig. 8). In general, Vs is higher on the southwestern end of the seismic profile and coincides with increases in elevation to the southwest. The higher Vs ( 400 m/s) rocks dip sharply to the northeast between distance meters 15 and 21, and likely correlate with the contact between more consolidated rock to the southwest and dominantly sedimentary rocks to the northeast.

The lowest values of $V s$ at the surface occur between distance meters 21 to 30 and meters 50 to 60 (fig. 8). Whereas, low Vs values between distance meters 50 to 60 may be related to thicker unconsolidated sediment accumulations, those between distance meters 21 to 25 occur at a major change in lithology, as inferred by the sharply higher $V s$ to the southwest. There is also a prominent surface Vs anomaly located between distance meters 40 and 45 and two southwesterly dipping minima in velocity contours; all of these velocity anomalies are likely related to SAF faulting.

\section{Vp/Vs Ratios}

The highest $V p / V s$ ratios (2.5) in the upper few meters of the subsurface are located at approximately distance meter 21 and between meters 30 and 40 (fig. 9). These locations coincide with likely zones of surface faulting inferred from $V p$ and $V s$ tomography images (fig. 9). However, below about $5 \mathrm{~m}$ depth, the highest $V p / V s$ ratios (as much as 7.5) occur in a near-vertical zone between these fault strands (distance meters 21 and 38 of the profile). We suggest that this near-vertical zone of high $V p / V s$ values likely coincides with the main SAF at depth. The apparent connection of this near-vertical fault with the known 1906 surface rupture (at distance meter 38) and our interpreted near-surface rupture (at distance meter 21) at depth suggests that the active SAF forms a flower structure in the upper 5 to $10 \mathrm{~m}$, with a northeast-dipping strand from distance meter 21 and a southwest-dipping strand from distance meter 38. However, it appears that the main SAF fault at depth may not extend vertically to the surface or much shallower than the $1,500 \mathrm{~m} / \mathrm{s}$ velocity contour (upper $3 \mathrm{~m}$ ) observed on the $V p$ model (fig. 7). The southwest dip of the zone of maximum $V p / V s$ values suggests that the 1906 surface rupture dips about 75 degrees to the southwest in the upper 10-20 m.

\section{Poisson's Ratio}

A tomographic Poisson's ratio model along the profile was developed from the $V p$ and $V s$ models for each grid point (fig. 10). Because Poisson's ratio can provide useful information about groundwater saturation and faulting (Catchings and others, 2013; 2014), we evaluated lateral variations in Poisson's ratio along our profile, where values range from about 0.26 to about 0.48 (fig. 10). The highest values below the depth of top of groundwater $(1,500 \mathrm{~m} / \mathrm{s}$ on fig. 7$)$ are centered near meter 30 . 
This zone of near-vertical high Poisson's ratio values also likely correlates with the main SAF at depth below $10 \mathrm{~m}$ (fig. 10). We also note relatively high near-surface Poisson’s ratio values near the 1906 surface rupture (meter 38) and near meter 21 (fig. 10) that likely coincide with faulting, as inferred from other velocity anomalies. The Poisson's ratio model suggest that most of the subsurface below about 5 $\mathrm{m}$ depth is water saturated, but a near-vertical zone near the center of the seismic profile has Poisson's ratio values of about 0.49 . Given that a value of 0.5 is characteristic of a fluid, this near-vertical zone of 0.49 values constitutes a highly anomalous zone that we interpret as the main SAF.

\section{Reflection Imaging}

We developed a seismic-reflection image by stacking reflected arrivals from the same seismic dataset using our $V p$ tomographic velocity model (fig. 11). However, because $V p$ was not available at all depths along our profile, we linearly extended the $V p$ model downward, and laterally across in the upper $20 \mathrm{~m}$. Below $20 \mathrm{~m}$ depth, velocities were estimated using 1-D velocity estimates.

We interpret continuous reflections as layer boundaries separating varying density and (or) seismic velocities. A stacked seismic-reflection image of the upper $200 \mathrm{~m}$ shows several reflectors in the upper $20 \mathrm{~m}$, although it is not possible to follow these reflectors continuously across the entire profile likely due to the complex geology (fig. 11). The only area with semicontinuous $(\sim 10 \mathrm{~m})$ reflectors is near the northeastern part of the profile in the upper $20 \mathrm{~m}$; these reflectors likely represent laterally continuous unconsolidated Holocene sediments.

Whereas the stacked reflection image does not exhibit strong laterally continuous reflectors along the entire seismic-reflection profile, there are prominent near-vertical alignments of diffractions, with the most prominent diffractions between distance meters 25 to 30 at depths between 30 to $100 \mathrm{~m}$ (fig. 11). Other near-vertical diffractions are apparent between meters 20 and 50 in the upper $30 \mathrm{~m}$. We interpret these near-vertically aligned diffractions as indicators of faults. Whereas diffractions can be generated by structures other than faults, the fact that they are aligned near-vertically and correlate with other seismic anomalies suggests that the diffractions are generated by faults. At meter 38, the location of the 1906 surface rupture, the apices of these diffractions are located progressively to the southwest with depth, suggesting the fault here dips toward the southwest. The prominent diffractions at about distance meter 25 are centered directly below the P-wave high-velocity zone and the zone of high $\mathrm{Vp} / \mathrm{Vs}$ ratios, both of which are indicative of fault zones (figs. 11 and 12). The diffractions on either side of this area appear to converge with those in the middle, especially the diffractions beneath the 1906 surface rupture at distance meter 38, suggesting that the fault strands merge at depth (fig. 11B).

The P- and S-wave velocity models, along with the $V p / V s$ ratios model, were each superimposed on the seismic-reflection image (fig. 12). The low-velocity, S-wave material in the upper few meters on the northeast portion of the profile, (unconsolidated sediments) appears to correlate with relatively continuous reflections here (fig. $B$. The P-wave, high-velocity zone, and the highest $V p / V s$ ratios correlate with the strongest diffractions on the seismic-reflection image at depth, further supporting our interpretation that this is the main SAF (figs. $12 A$ and $12 C$, respectively). About $5 \mathrm{~m}$ of sediment overlie areas that correlate with diffractions, suggesting this fault may be older than the 1906 surface rupture.

\section{Borehole Observations}

To investigate the lithology of near-surface materials, we hand-augered a 6-m-deep borehole at distance meter 25 of the profile (figs. 7-10). The upper $1.5 \mathrm{~m}$ of the borehole contained unconsolidated sediments with low moisture content (fig. 13). Static water depth was observed at about $3 \mathrm{~m}$ depth, which correlates well with the 1,500 m/s contour observed on the $V p$ model (fig. 7) and with the depth to the top of groundwater observed in the southwestern side of the paleoseismic trench near meter 38 
(Zachariasen and others, 2011). Through the upper section of the borehole (upper $4.5-5 \mathrm{~m}$ ), we observed coarse gravel mixed with variously colored clay and rock fragments, and within the bottom 1 $\mathrm{m}$ of the borehole, we observed compact, moist blue clay (fig. 13). The blue clay may have originated from serpentinite, as it is similar in appearance to weathered serpentinite observed along the active trace of the SAF in other nearby locations (Catchings and others, 2013; M. Rymer, oral commun. 2013). Our seismic tomography model suggests that the seismic $V p$ of this water-saturated clay unit ranges from about 2000 to 2,800 m/s at about 5 to $6 \mathrm{~m}$ depth (fig. 7). Between distance meters 21 and 25, we noted a small slope in the $1,500 \mathrm{~m} / \mathrm{s} V p$ contour, suggesting a partial groundwater barrier and a secondary fault strand at this depth..

\section{Comparison with Previous Geophysical Studies}

There are few seismic imaging investigations of the subsurface structure of the Peninsula segment of the SAF, but two recent seismic investigations, using identical acquisition and processing methods (Catchings and others, 2013, 2014), show similar results to those found in this study. Catchings and others (2013) acquired and analyzed high-resolution seismic data from San Andreas Lake, approximately $15 \mathrm{~km}$ northwest of our study location (fig. 1). They acquired three seismic profiles that showed complex subsurface faulting within about $100 \mathrm{~m}$ of the 1906 surface rupture of the SAF (Catchings and others, 2013). Catchings and others (2013) correlated at least three additional nearsurface fault strands within about $20 \mathrm{~m}$ of the 1906 surface rupture to previously mapped traces, and they found that the width of the main fault zone appears to vary slightly along strike. Their observation of additional fault strands near the 1906 surface rupture is consistent with our observation of at least one additional fault strand west of the 1906 surface rupture. At a separate site located between San Andreas Lake and Lower Crystal Springs reservoirs, Catchings and others (2014) found Vp, Vs, Vp/Vs, and Poisson's ratio values along the 1906 surface rupture zone of the SAF similar to those reported in this study. Similar variations in P- and S-wave velocities and abrupt changes in the depth to the top of groundwater across the fault strands were also found in each study in the area.

\section{Comparison with Paleoseismic Work}

Zachariasen and others (2011) evaluated two paleoseismic trenches perpendicular to the trace of the SAF, which our seismic profile crossed (fig. 4). They observed concentrated faulting within $2 \mathrm{~m}$ of the 1906 surface rupture, but their mapped traces do not break the current ground surface or layers within about $2 \mathrm{~m}$ of the surface (Zachariasen and others, 2011); this is also consistent with our interpreted reflection image. Their observed fault zone occurs at about distance meter 38 of our seismic profile, where we also observed seismic evidence of faulting. However, their trench did not extend farther southwest to our interpreted main fault zone, nor to our inferred near-surface fault at distance meter 21.

The fact that our main-fault-zone seismic anomaly extends only to within 3 to $5 \mathrm{~m}$ of the surface and the 1906 surface rupture extends only to within $2 \mathrm{~m}$ of the surface suggests that sedimentation rates at our study area may be high enough to deposit between 1 to $2 \mathrm{~m}$ of sediment between major events. Thus, it may be necessary to excavate trenches that are 5 to $6 \mathrm{~m}$ deep to expose older events.

\section{Discussion and Conclusions}

A zone of relatively low $V p$, low $V s$, high $V p / V s$, and high Poisson's ratio in the upper few meters (vadose zone) near distance meter 38 of our seismic profile (figs. 7, 8, 9, and 10, respectively) correlates with the 1906 surface rupture of the SAF (Zachariasen and others, 2011). A vertical offset in 
the $1,500 \mathrm{~m} / \mathrm{s}$ velocity contour, which coincides with the depth to the top of groundwater, also occurs near meter 38, and on our reflection image we observe a zone of dipping diffractions in the same area. These seismic observations are consistent with the presence of a southwest-dipping fault associated with the 1906 surface rupture. At about distance meter 21 of the seismic profile, we observe a similar nearsurface anomaly in all datasets, but our interpreted secondary fault dips to the northeast. At about 5-20 $\mathrm{m}$ beneath the ground surface and centered at about distance meter 27 of the seismic profile, we observe an anomalous zone of high $V p$, low $V s$, high $V p / V s$, and high Poisson's ratio. An augered borehole into the top of the anomalous zone shows that it is composed of water-saturated blue clay, which may be derived from weathered serpentinite, which has been found elsewhere within the active fault zone. At depths in excess of about $30 \mathrm{~m}$, the zone is marked by prominent diffractions on our reflection image. Collectively, we interpret this zone as the main active strand of the SAF in our study area. However, it appears that the main fault strand does not extend vertically to the surface, but extends only to within about 3 to $5 \mathrm{~m}$ of the surface. We interpret the near-surface fault strands near distance meters 21 (secondary fault strand) and 38 (1906 surface rupture) to dip toward the main fault zone, effectively forming a flower structure that is typical of strike-slip faults.

Based on previous observations of the 1906 rupture zone (Schussler, 1906), secondary nearsurface fault strands can also slip during earthquakes. In such a case, paleoseismic measurements made on a single fault strand would not capture the total slip during past earthquakes on the SAF. Because our study found evidence for more than one near-surface strand of the SAF, it is possible that some of the reported slip rates and event histories for the Peninsula segment of the SAF are minimum values that only account for slip on one of several active surface fault traces. It would imply that the overall slip rate for the SAF is underestimated, particularly if slip does not always occur on a given near-surface rupture zone. If our interpretation of a high sedimentation rate at our study area is accurate, we suggest that it may be necessary to excavate trenches deeper than $5 \mathrm{~m}$ to access the main fault zone and to evaluate older slip events. Evaluating newly inferred faults may increase the overall measured slip rate and history, which may change hazard determinations for the Peninsula segment of the SAF.

\section{Acknowledgments}

We thank the San Francisco Public Utilities Commission for access to their property. We thank Alex Barker, Leah Campbell, Coyn Criley, Neil Fenning, Alex Ferguson, Will Hassett, Jim Leinkaemper, Elizabeth Rose, and Robert Sickler for field assistance. We thank Carol Prentice and Judy Zachariasen for data from their Paleoseismic trench at our study area. We thank the U.S. Geological Survey Earthquake Hazards Program and the USGS Earthquake Science Center's High Resolution Imaging Group for providing funding for the seismic study. Reviews and suggestions by Leonard Sklar and by Suzanne Hecker and Gary Fuis are greatly appreciated. 


\section{References Cited}

Aki, K., and Lee, W.H.K., 1976, Determination of three-dimensional velocity anomalies under a seismic array using P-arrival times from location earthquakes-1. A homogeneous initial model: Journal of Geophysical Research, v. 81, p. 4381-4399.

Bakun, W.H., 1999, Seismic Activity of the San Francisco Bay Region: Bulletin of the Seismological Society of America, v. 89, p. 764-784.

Baldwin, J., Prentice, C.S., Wetenkamp, J., and Sundermann, S., 2006, Preliminary earthquake record of the Peninsula section of the San Andreas fault, Portola Valley, California: Seismological Research Letters, v. 77, p. 248.

Baldwin, J., and Prentice, C.S., 2008, Earthquake records of the Peninsula segment of the San Andreas fault, Portola Valley, California: Collaborative research with William Lettis \& Associates, Inc. and U.S. Geological Survey, Final Technical Report, U.S. Geological Survey National Earthquake Hazards Reduction Program Award Number 05HQGR0073, 41 p.

Brabb, E.E., Graymer, R.W., and Jones, D.L., 2000, Geologic map and map database of the Palo Alto 30' X 60' quadrangle, California: U.S. Geological Survey Miscellaneous Field Studies Map MF-2332, scale: $1: 100,000$.

Bredehoeft, J.D., Belitz, K., and Sharp-Hansen, S., 1992, The hydrodynamics of the Big Horn Basin-A study of the role of faults: American Association of Petroleum Geologists Bulletin, v. 76, p. 530-546.

Catchings, R.D., Cox, B.F., Goldman, M.R., Gandhok, G., Rymer, M.J., Dingler, J., Martin, P., Christensen, A., and Horta, E., 2000, Subsurface structure and seismic velocities as determined from high-resolution seismic imaging in the Victorville, California area; Implications for water resources and earthquake hazards: U.S. Geological Survey Open-File Report 2000-123, 70 p.

Catchings, R.D., Gandhok, G., Goldman, M.R., Horta, E., Rymer, M.J., Martin, P., and Christensen, A., 1999, Subsurface, high-resolution, seismic images from Cherry Valley, San Bernardino County, California; Implications for water resources and earthquake hazards: U.S. Geological Survey OpenFile Report 99-26, 57 p.

Catchings, R.D., Goldman, M.R., and Gandhok, G., 2006, Structure and velocities of the northeastern Santa Cruz Mountains and the western Santa Clara Valley, California, from the SCSI-LR seismic survey: U.S. Geological Survey Open-File Report 2006-1014, 78 p.

Catchings, R.D., Rymer, M.J., Goldman, M.R., and Gandhok, G., 2009, San Andreas fault geometry at Desert Hot Springs, California, and its effects on earthquake hazards and groundwater: Bulletin of the Seismological Society of America, v. 99, p. 2190-2207.

Catchings, R.D., Rymer, M.J., Goldman, M.R., Hole, J.A., Huggins, R., and Lippus, C., 2002, Highresolution seismic velocities and shallow structure of the San Andreas fault zone at Middle Mountain, Parkfield, California: Bulletin of the Seismological Society of America, v. 92, p. 2493-2503.

Catchings, R.D., Rymer, M.J., Goldman, M.R., Prentice, C.S., and Sickler, R.R., 2013, Fine-scale delineation of the location of and relative ground shaking within the San Andreas fault zone at San Andreas Lake, San Mateo County, California: U.S. Geological Survey Open-File Report 2013-1041, $58 \mathrm{p}$.

Catchings, R.D., Rymer, M.J., Goldman, M.R., Sickler, R.R., and Criley, C.J., 2014, A method and example of seismically imaging near-surface fault zones in geologically complex areas using $\mathrm{Vp}$, Vs, and their ratios, Bulletin of the Seismological Society of America, v. 104, p. 1989-2006.

Chester, F.M., and Logan, J.M., 1986, Composite planar fabric of gouge from the Punchbowl fault, California: Journal of Structural Geology, v. 9, p. 621-634.

Chester, J.S., Chester, F.M., and Kronenberg, A.K., 2005, Fracture surface energy of the Punchbowl fault, San Andreas system: Nature, v. 437, p. 133-136. 
Clark, M.M., 1984, Map showing recently active breaks along the San Andreas Fault and associated faults between Salton Sea and Whitewater River-Mission Creek, California: U.S. Geological Survey Miscellaneous Investigation Series Map I-1483, 2 sheets, scale 1:24,000.

Dutcher, L.C., and Garrett, A.A., 1963, Geologic and hydrologic features of the San Bernardino area, California—with special reference to underflow across the San Jacinto fault: U.S. Geological Survey Water Supply Paper 1419, 114 p.

Field, E.H., Biasi, G.P., Bird, P., Dawson, T.E., Felzer, K.R., Jackson, D.D., Johnson, K.M., Jordan, T.H., Madden, C., Michael, A.J., Milner, K.R., Page, M.T., Parson, T., Powers, P.M., Shaw, B.E., Thatcher, W.R., Weldon, R.J., II, and Zeng, Y., 2015, Long-Term Time-Dependent Probabilities for the Third Uniform California Earthquake Rupture Forecast (UCERF3): Bulletin of the Seismological Sociecty of America, v. 105, n. 2A.

Flinn, D, 1977, Transcurrent faults and associated cataclasis in Shetland: Journal of the Geological Society of London, v. 133, p. 231-247.

Graymer, R.W., Moring, B.C., Saucedo, G.J., Wentworth, C.M., Brabb, E.E., and Knudsen, K.L., 2006, Geologic map of the San Francisco Bay region: U.S. Geological Survey Scientific Investigations Map 2918, scale 1:275,000. [Available at http://pubs.usgs.gov/sim/2006/2918/.]

Gupta, V., and Bergstrom, J.S., 1998, Compressive failure of rocks by shear faulting: Journal of Geophysical Research, v. 103, p. 23875-23895.

Hall, N.T., 1984, Holocene History of the San Andreas fault between Crystal Springs Reservoir and San Andreas Dam, San Mateo County, California: Bulletin of the Seismological Society of America, v. 74, p. 281-299.

Hall, N.T., Wright, R.H., and Clahan, K.B., 1999, Paleoseismic studies of the San Francisco Peninsula segment of the San Andreas fault zone near Woodside, California: Journal of Geophysical Research, v. 104, p. 23215-23236.

Hall, N.T., Wright, R.H., and Prentice, C.S., 2001, Studies along the Peninsula segment of the San Andreas fault, San Mateo and Santa Clara Counties, California, in Ferriz, H., and Anderson, R., eds., Engineering Geology Practice in Northern California: California Division of Mines and Geology, Bulletin 210, Special Publication 12, p. 193-210.

Han, D., Nur, A., and Morgan, D., 1986, Effects of porosity and clay content on wave velocities in sandstones: Geophysics, v. 51, p. 2093-2107.

Haneberg, W.C., 1995, Steady state groundwater flow across idealized faults: Water Resources Research, v. 31, p. 1815-1820.

Healy, J.H., and Peake, L.G., 1975, Seismic velocity structure along a section of the San Andreas Fault near Bear Valley, California: Bulletin of the Seismological Society of America, v. 65, p. 1177-1197.

Hole, J.A., 1992, Nonlinear high-resolution three-dimensional seismic travel time tomography: Journal of Geophysical Research, v. 97, p. 6553-6562.

Irwin, W.P., 1990 Geology and plate-tectonic development, chap. 3 of Wallace, R.E., ed., The San Andreas Fault system, California: U.S. Geological Survey Professional Paper 1515, p. 61-80.

Kelson, K.I., Simpson, G.D., Lettis, W.R., and Haraden, C.C., 1996, Holocene slip rate and recurrence of the northern Calaveras fault at Leyden Creek, northern California: Journal of Geophysical Research, v. 101, p. 5961-5975.

Kissling, E, Husen, S, and Haslinger, F., 2001, Model Parameterization in seismic tomography-a choice of consequence for the solution quality: Physics of the Earth and Planetary Interiors, v. 123, p. 89-101.

Lawson, A.C., 1908, The California Earthquake of April 18, 1906, Report of the State Earthquake Investigation Commission: Carnegie Institution of Washington, v. 1, no. 87, 451 p. 
Li, Y. -G., and Leary, P.C., 1990, Fault zone trapped seismic waves: Bulletin of the Seismological Society of America, v. 80, p. 1245-1271.

Mayer-Rosa, D, 1973, Travel time anomalies and distribution of earthquakes along the Calaveras fault zone, California: Bulletin of the Seismological Society of America, v. 72, p. 901-910.

Mooney, W.D., and Ginzburg, A., 1986, Seismic measurements of the internal properties of fault zones: Pure and Applied Geophysics, v. 124, p. 141-157.

Mooney, W.D., and Luetgert, J.H., 1982, A seismic refraction study of the Santa Clara Valley and southern Santa Cruz Mountains, west central California: Bulletin of the Seismological Society of America, v. 72, p. 901-909.

Page, B.M., 1981, The southern Coast Ranges, in Ernst, W.G., ed., The geotectonic development of California (Rubey Volume 1): Englewood Cliffs, New Jersey, Prentice-Hall, p. 329-417.

Pampeyan, E.H., 1994, Geologic map of the Montara Mountain and San Mateo 7-1/2' quadrangles, San Mateo County, California: U.S. Geological Survey Miscellaneous Investigation Series Map I-2390, scale $1: 24,000$.

Parsons, T., and Zoback, M.L., 1997, Three-dimensional upper crustal velocity structure beneath San Francisco Peninsula, California: Journal of Geophysical Research, v. 102, p. 5473-5490.

Prentice, C.S., 1999, San Andreas fault: The 1906 earthquake and subsequent evolution of ideas, in Moores, E.M., Sloan, D, and Stout, D.L., eds., Classic Cordilleran Concepts-A View from California: Boulder, Colorado, Geological Society of America Special Paper 338, p. 79-85.

Prentice, C.S., and Moreno, X., 2007, Paleoseismic site on the Peninsula San Andreas fault near Crystal Springs Reservoir-Preliminary results: Seismological Research Letters, v. 78, p. 315.

Prentice, C.S., Sickler, R.R., Hecker, S., Schwartz, D.P., and Brown, J., 2008, Preliminary results from a new paleoseismic site on the San Andreas fault near Crystal Springs Reservoir, San Francisco Peninsula, California: Seismological Research Letters, v. 79, p. 360.

Proctor, R.J., 1968, Geology of the Desert Hot Springs-Upper Coachella Valley area, California: California Division of Mines and Geology Special Report, v. 94, 50 p.

Rymer, M.J., Hickman, S.H., and Stoffer, P.W., 2006, A field guide to the central, creeping section of the San Andreas fault and the San Andreas Fault Observatory at Depth, in Prentice, C.S., Scotchmoor, J.G., Moores, E.M., and Kiland, J.P., eds., 1906 San Francisco Earthquake Centennial Field Guides: Fieldtrips associated with the $100^{\text {th }}$ Anniversary conference, 18-23 April 2006, San Francisco, California: Geological Society of America Field Guide 7., p. 237-272, doi: 10.1130/2006.1906SF(16).

Savage, J.C., Svarc, J.L., and Prescott, W.H., 1999, Geodetic estimates of fault slip rates in the San Francisco Bay area: Journal of Geophysical Research, v. 104, p. 4995-5002.

Schussler, H., 1906, The water supply of San Francisco, California, before, during, and after the earthquake of April 18, 1906 and the subsequent conflagration. New York, Martin B. Brown Press, $103 \mathrm{p}$.

Sibson, R.H., 2003, Thickness of the seismic slip zone: Bulletin of the Seismological Society of America, v. 93, p. 1169-1178.

Sleep, N.H., and Fujita, K., 1997, Principles of Geophysics: Massachusetts, Blackwell Science, 586 p.

Spudich, P., and Angstman, B., 1980, Lateral variations in velocity and Q structure in the region of the 1979 Coyote Lake, California, earthquake: Earthquake Notes, v. 50, p. 64.

Stoffer, P., 2002, Rocks and Geology of the San Francisco Bay Region: U.S. Geological Survey Bulletin 2195, 64 p.

Thomsen, L., 1990, Poisson was not a geophysicist!: The Leading Edge, v. 9, p. 27-29, doi:10.1190/1.1439706. 
Thurber, C. H., 1983, Earthquake locations and three-dimensional crustal structure in the Coyote Lake area, central California: Journal of Geophysical Research, v. 88, p. 8226-8236.

Tolman, C.F., 1937, Ground water: New York, McGraw-Hill, 593 p.

Toppozada, T.R., and Borchardt, G., 1998, Re-evaluation of the 1836 “Hayward Fault” and the 1838

San Andreas Fault Earthquakes: Bulletin of the Seismological Society of America, v. 88, p. 140-159.

Wallace, R.E., 1990, General Features, chap. 1 of Wallace, R.E., ed., The San Andreas Fault system, California: U.S. Geological Survey Professional Paper 1515, p. 3-13.

Wallace, R.E., and Morris, H.T., 1986, Characteristics of faults and shear zones in deep mines: Pure and Applied Geophysics, v. 124, p. 107-125.

Wang, C.Y., Lin, W, and Wu, F.T., 1978, Constitution of the San Andreas Fault zone at depth: Geophysical Research Letters, v. 5, p. 741-744.

Wilson, J.E., Chester, J.S., and Chester, F.M., 2003, Microfracture analysis of fault growth and wear processes, Punchbowl Fault, San Andreas system, California: Journal of Structural Geology, v. 25, p. 1855-1873.

Working Group on California Earthquake Probabilities (WGCEP), 2003, Earthquake Probabilities in the San Francisco Bay Region-2002-2031: U.S. Geological Survey Open-File Report 2003-214, 235 p.

Working Group (2007) on California Earthquake Probabilities (WGCEP), 2008, The Uniform California Earthquake Rupture Forecast, Version 2 (UCERF 2): U.S. Geological Survey Open-File Report 2007-1437, CGS Special Report 203, SCEC Contribution \#1138, v. 1.0, 104 p.

Working Group on California Earthquake Probabilities (WGCEP), 2013, Uniform California Earthquake Rupture Forecast, Version 3 (UCERF 3) — The time-independent mode: U.S. Geological Survey Open-File Report 2013-1165, 97 p., California Geological Survey Special Report 228, and Southern California Earthquake Center Publication 1792, http://pubs.usgs.gov/of/2013/1165/.

Wu, F.T., 1978, Mineralogy and physical nature of clay gouge: Pure and Applied Geophysics, v. 116, p. 655-689.

Zachariasen, J.A., Prentice, C.S., Kozaci, O., Sickler, R.R., Baldwin, J.N., Sanquini, A., and Knudsen, K.L., 2010, Paleoseismic study on the Peninsula segment of the San Andreas Fault south of Crystal Springs Reservoir, San Mateo County, California [abs.]: American Geophysical Union, Fall Meeting 2010, abstract \#S21C-2048.

Zachariasen, J.A., Baldwin, J.N., Kozaci, O., and Prentice, C., 2011, Paleoseismic investigations of Holocene earthquake recurrence on the Peninsula segment of the San Andreas fault, Woodside, CA: Final Technical Report for USGS National Earthquake Hazard Reduction Program Award Number G09AP00048, 32 p. 
Table 1. Relevant previous paleoseismic studies on the Peninsula Segment of the San Andreas Fault (see fig. 3).

[km, kilometer; m, meter; mm/yr, millimeter per year]

\begin{tabular}{|c|c|c|c|}
\hline Study & Location & Slip rate & Other notable findings \\
\hline Hall and others , 1999 & $\begin{array}{l}\text { Filoli Estate, } \\
\text { Woodside, CA }\end{array}$ & $\begin{array}{l}17 \pm 4 \\
\mathrm{~mm} / \mathrm{yr}\end{array}$ & $\begin{array}{l}\text { Evidence for } 1906 \text { event. Proposed } \\
\text { evidence for } 1838 \text { event based on channel } \\
\text { deposit (dated at } 330 \pm 200 \text { years B.P.), } \\
\text { but refuted by Zacharaisen and others, } \\
2010 \text {. }\end{array}$ \\
\hline $\begin{array}{l}\text { Prentice and Moreno, } \\
\text { 2007; Prentice and } \\
\text { others, } 2008\end{array}$ & $\begin{array}{l}10 \text { km northwest of our } \\
\text { study area, at north } \\
\text { end of Lower Crystal } \\
\text { Springs Reservoir }\end{array}$ & & $\begin{array}{l}\text { Identified } 1906 \text { rupture and one previous } \\
\text { event; age constraints suggest older event } \\
\text { occurred A.D. 890-1260. }\end{array}$ \\
\hline $\begin{array}{l}\text { Prentice and others, } \\
2008\end{array}$ & Same location as above & & $\begin{array}{l}\text { Evidence for } 1906 \text { rupture and no previous } \\
\text { event in their 3-m deep exposure. }\end{array}$ \\
\hline $\begin{array}{l}\text { Baldwin and others, } \\
\text { 2006; Baldwin and } \\
\text { Prentice, } 2008\end{array}$ & $\begin{array}{l}16 \text { km southeast of our } \\
\text { study area, Portola } \\
\text { Valley, CA }\end{array}$ & & $\begin{array}{l}\text { Evidence for at least three, possibly four } \\
\text { pre-1906 events in } 1,000 \text { years; no } \\
\text { evidence for } 1838 \text { event. }\end{array}$ \\
\hline $\begin{array}{l}\text { Zachariasen and } \\
\text { others, } 2011\end{array}$ & $\begin{array}{l}\text { South end of Upper } \\
\text { Crystal Springs } \\
\text { Reservoir (at location } \\
\text { of this study) }\end{array}$ & & $\begin{array}{l}\text { Evidence for } 1906 \text { and previous event } 600- \\
1,000 \text { years ago; no evidence for } 1838 \\
\text { event. }\end{array}$ \\
\hline
\end{tabular}



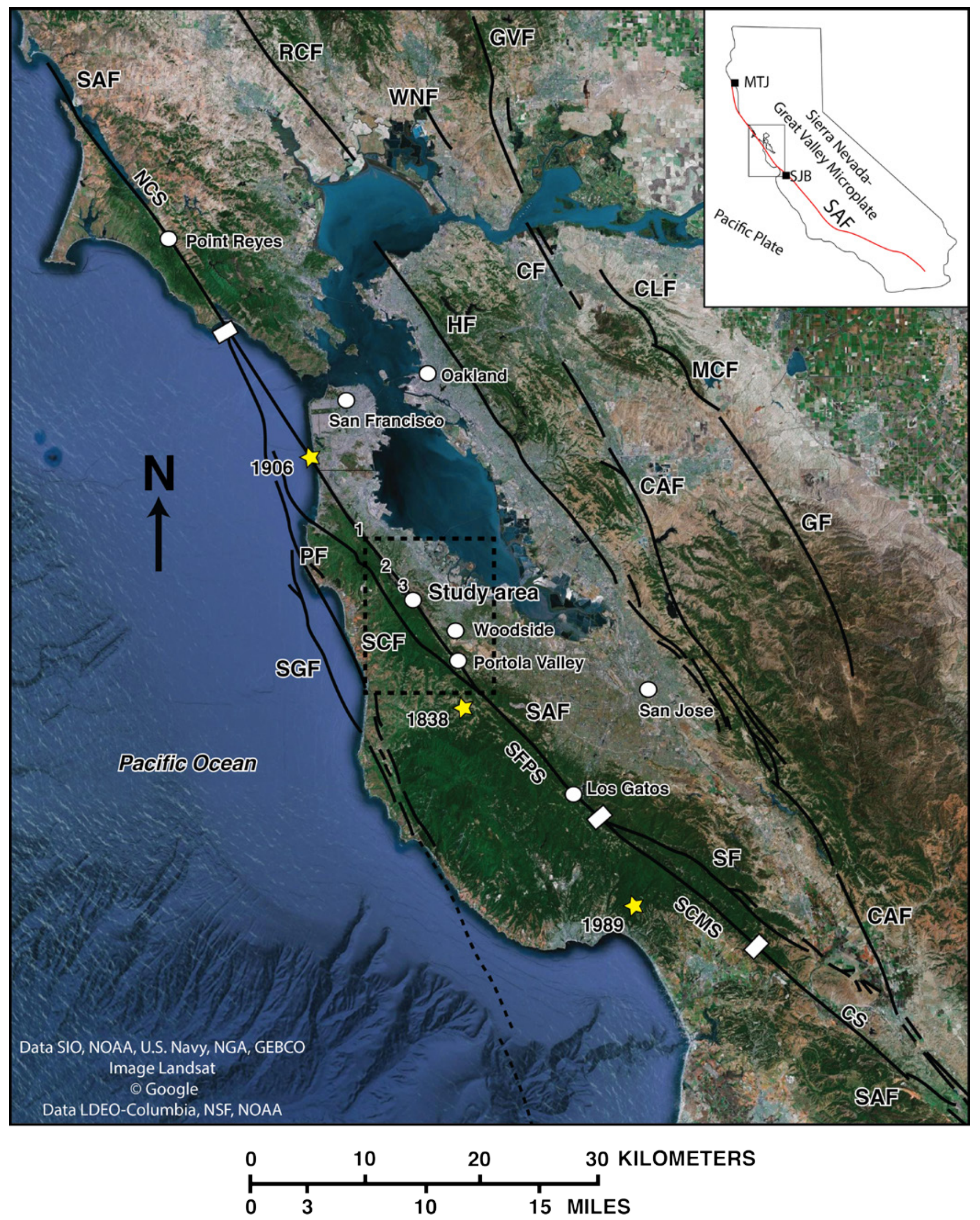
Figure 1. (Previous page) Annotated Google (2013) satellite imagery map of San Francisco Bay Area showing major faults (Graymer and others, 2006), various cities, our study area, and estimated major historical earthquake epicenters (WGCEP, 2003) along the San Andreas Fault (SAF). Study area is located at Filoli Center. Inset map shows State of California, SAF, Pacific and Sierra Nevada-Great Valley Microplate, and the Medincino Triple Junction (MTJ). Abbreviations: SJB, San Juan Bautista; CAF, Calaveras Fault; CF, Concord Fault; GF, Greenville Fault; GVF, Green Valley Fault; HF, Hayward Fault; MCF, Marsh Creek Fault; PF, Pilarcitos Fault; RCF, Rodgers Creek Fault; WNF, West Napa Fault; SCF, Seal Cove Fault; SGF, San Gregorio Fault; and SF, Sargent Fault. Symbols: White rectangles indicate fault segment boundaries of northern California SAF (from north to south, NCS, North Coast; SFPS, San Francisco Peninsula; SCMS, Santa Cruz Mountains), and boundary between northern and central California (CS) sections. Yellow stars show historical earthquake epicenters (1906, M7.9; 1989, M6.9; 1838, $\sim 6.8-7.4$ ). Numbers correspond to locations: 1, San Andreas Lake; 2, Lower Crystal Springs Reservoir; 3, Upper Crystal Springs Reservoir. Dashed black box outlines location of figure 3. 

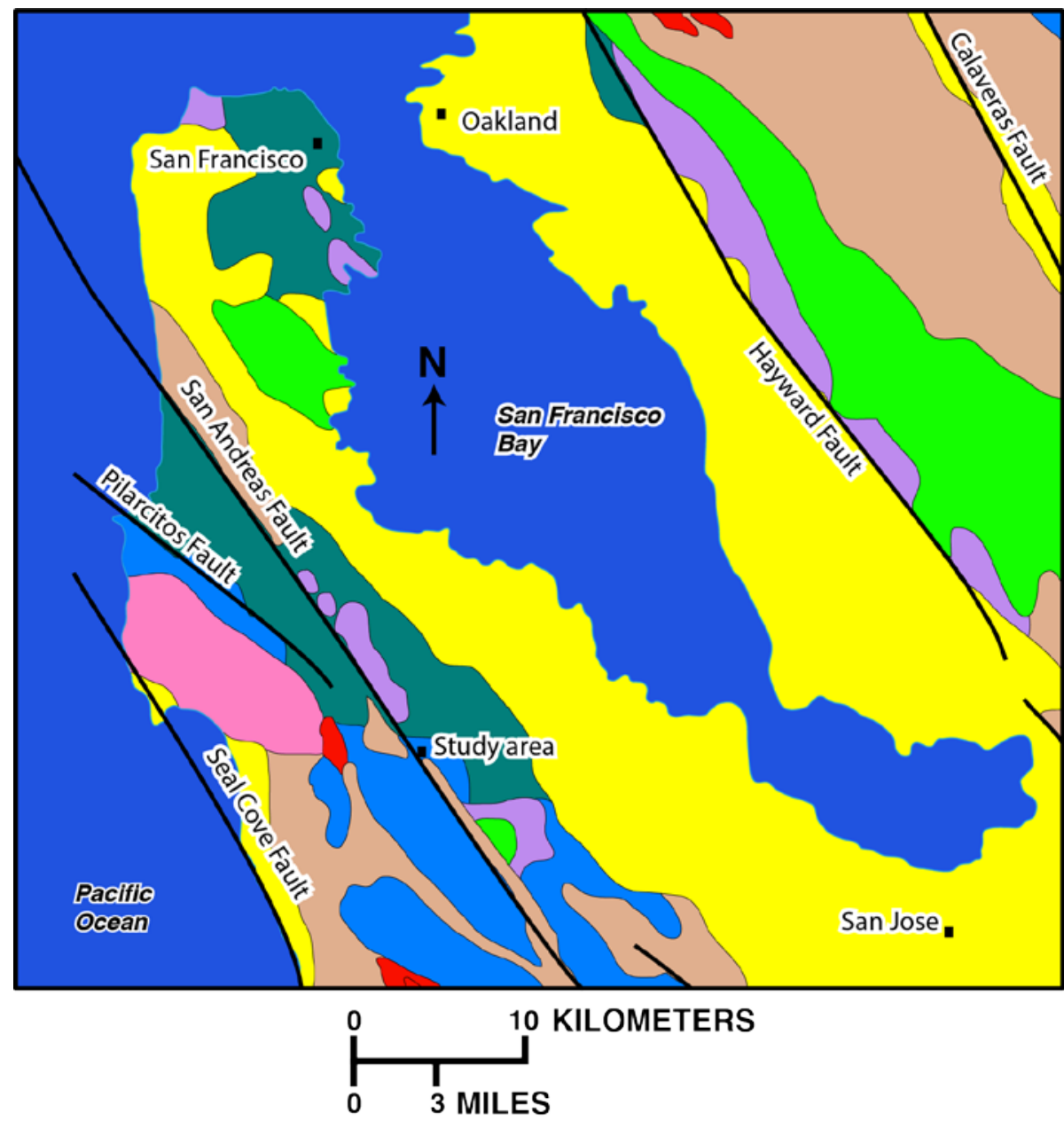

\section{EXPLANATION}

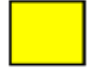

Quaternary sediments

Neogene sedimentary rocks

Miocene-Oligocene volcanic rocks

Paleogene sedimentary rocks
Cretaceous-Late Jurassic sedimentary rocks

Cretaceous-Jurassic Franciscan sandstone, chert, basalt, limestone, mélange, etc.

Jurassic Franciscan Serpentinite (ultramafic rocks)

Mesozoic Salinian plutonic rocks

Fault

Figure 2. Generalized geologic map of the San Francisco Peninsula and East Bay regions showing bedrock units, surficial deposits, principal faults, and cities. Adapted from Stoffer (2002). 


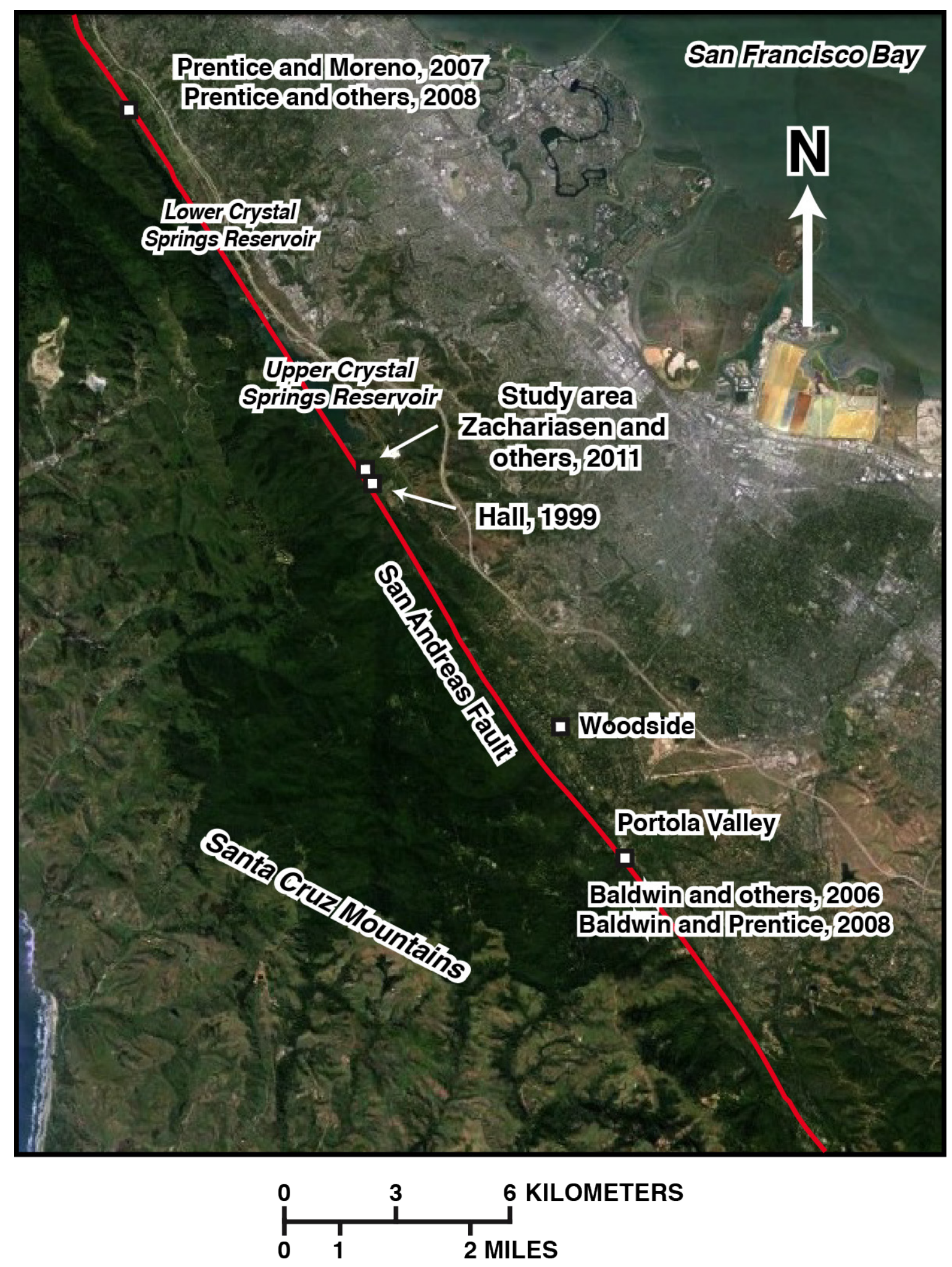

Figure 3. Annotated Google Earth (2013) image showing study area location and previous paleoseismic sites. Red line denotes San Andreas Fault (Graymer and others, 2006). Paleoseismic study sites discussed in text are shown as white squares. 

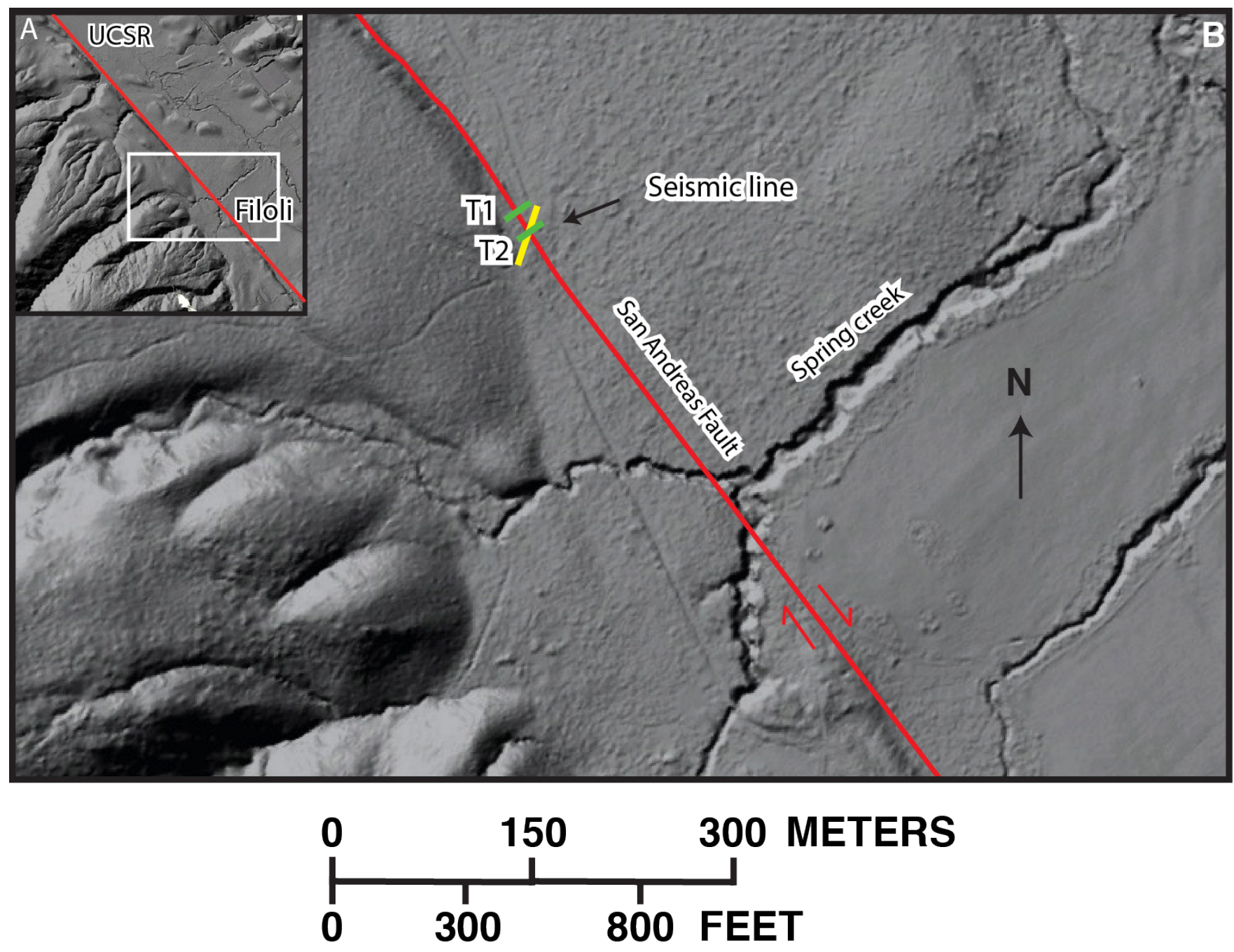

Figure 4. A, Lidar image from National Science Foundation Geoearthscope showing study area location (white rectangle) relative to Upper Crystal Springs Reservoir (UCSR) and the Filoli Center (Filoli). B, Lidar of the study area showing seismic line location (yellow line) and locations of two trenches (green lines; T1 and T2) opened by Zachariasen and others (2011). Main trace of San Andreas Fault (Graymer and others, 2006) is shown as red line in $(A)$ and $(B)$.Red paired arrows show dominantly dextral slip along fault. 


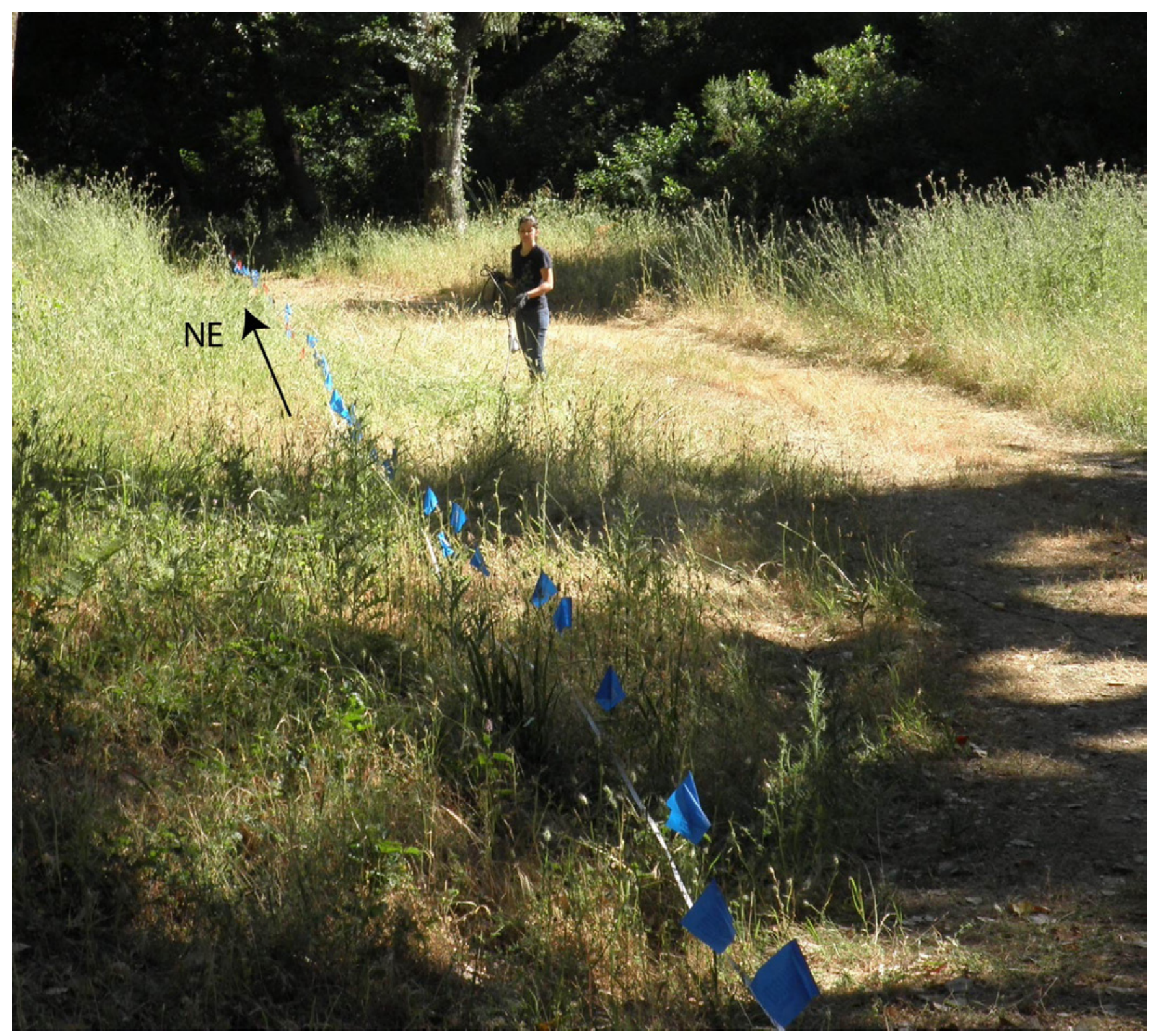

Figure 5. Photograph showing field site and locations (blue flags) of shots and geophones used in our seismic survey. (USGS photograph by Rufus Catchings, June 15, 2012) 


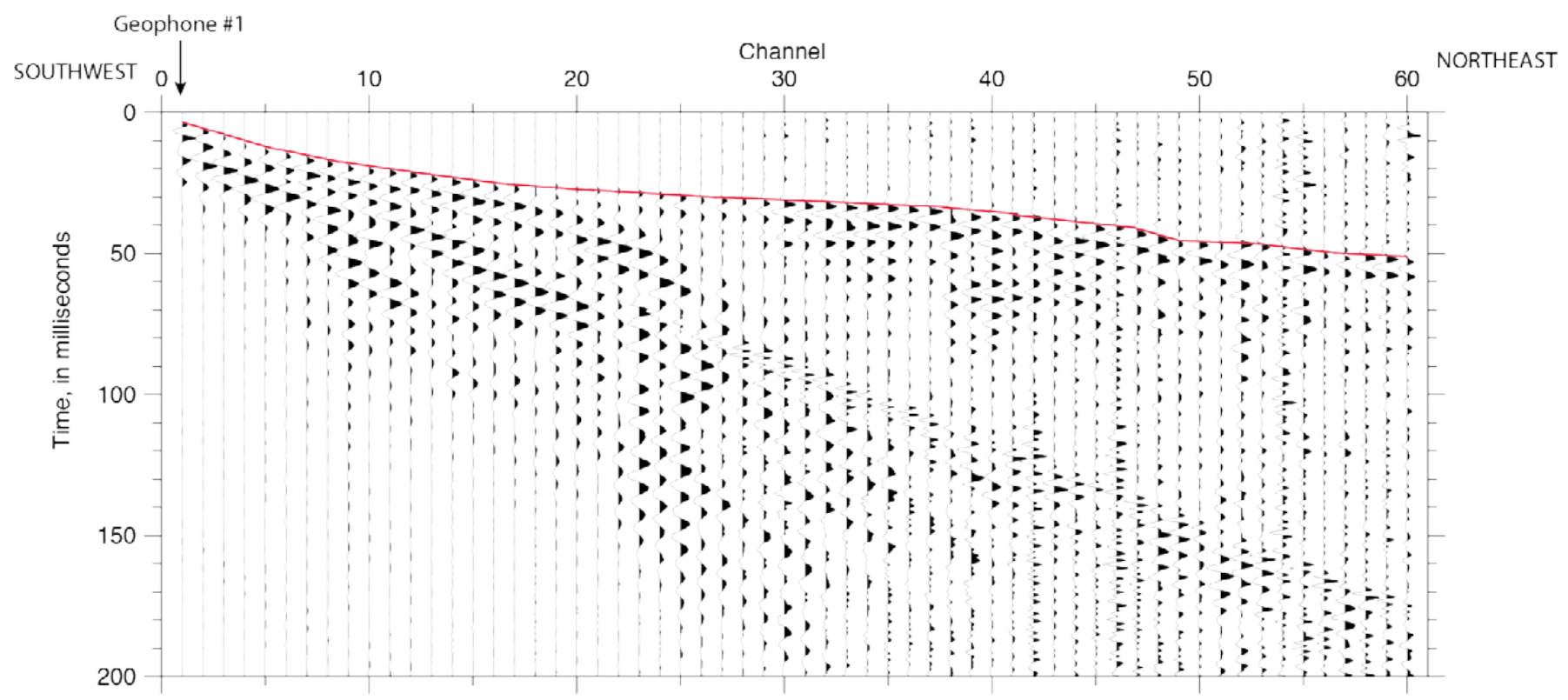

Figure 6. Graph showing example shot gather with shot point (source) located at southwestern end of profile at geophone \#1 (also shotpoint \#1). Vertical axis is time, in milliseconds (ms) and horizontal axis is channel number of recording geophones, which is equivalent to distance along profile, in meters. Each vertical "wiggle line" is a trace. Red line shows first-arrival times measured for seismic-refraction analysis. 


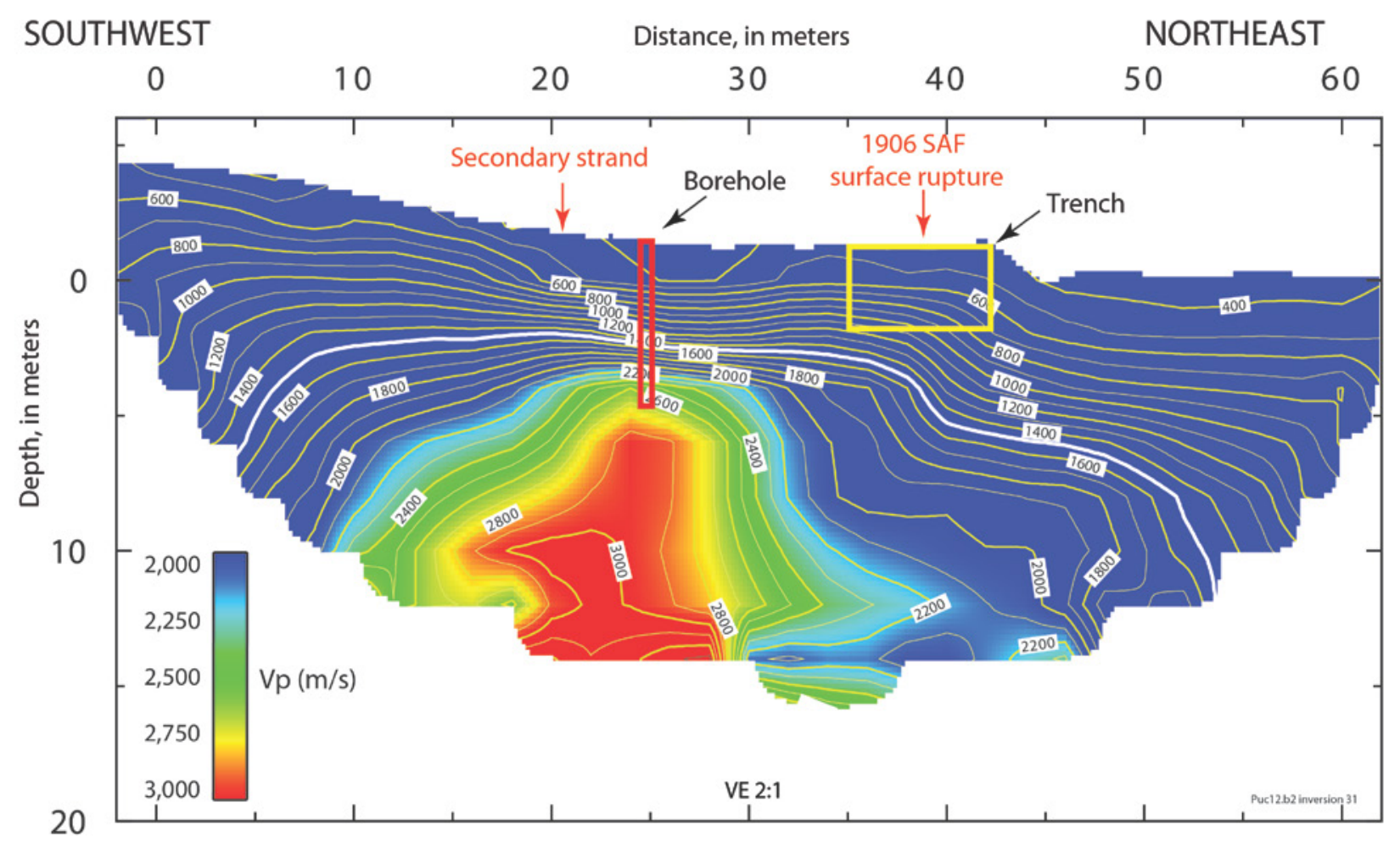

Figure 7. P-wave refraction tomography velocity model for our San Andreas Fault (SAF) profile. Red arrows point to locations of 1906 surface rupture (correlated to fault in trench) at distance meter 38 and possible secondary fault strand at distance meter 21 . The $1,500 \mathrm{~m} / \mathrm{s}$ contour (white line) correlates with depth to top of groundwater. A significant fault strand within the P-wave, high-velocity zone is located at distance meter 27 and is interpreted to be location of main San Andreas Fault (SAF) zone at depth. Red and yellow boxes show hand-augered borehole and trench locations, respectively, by Zachariasen and others (2011). 


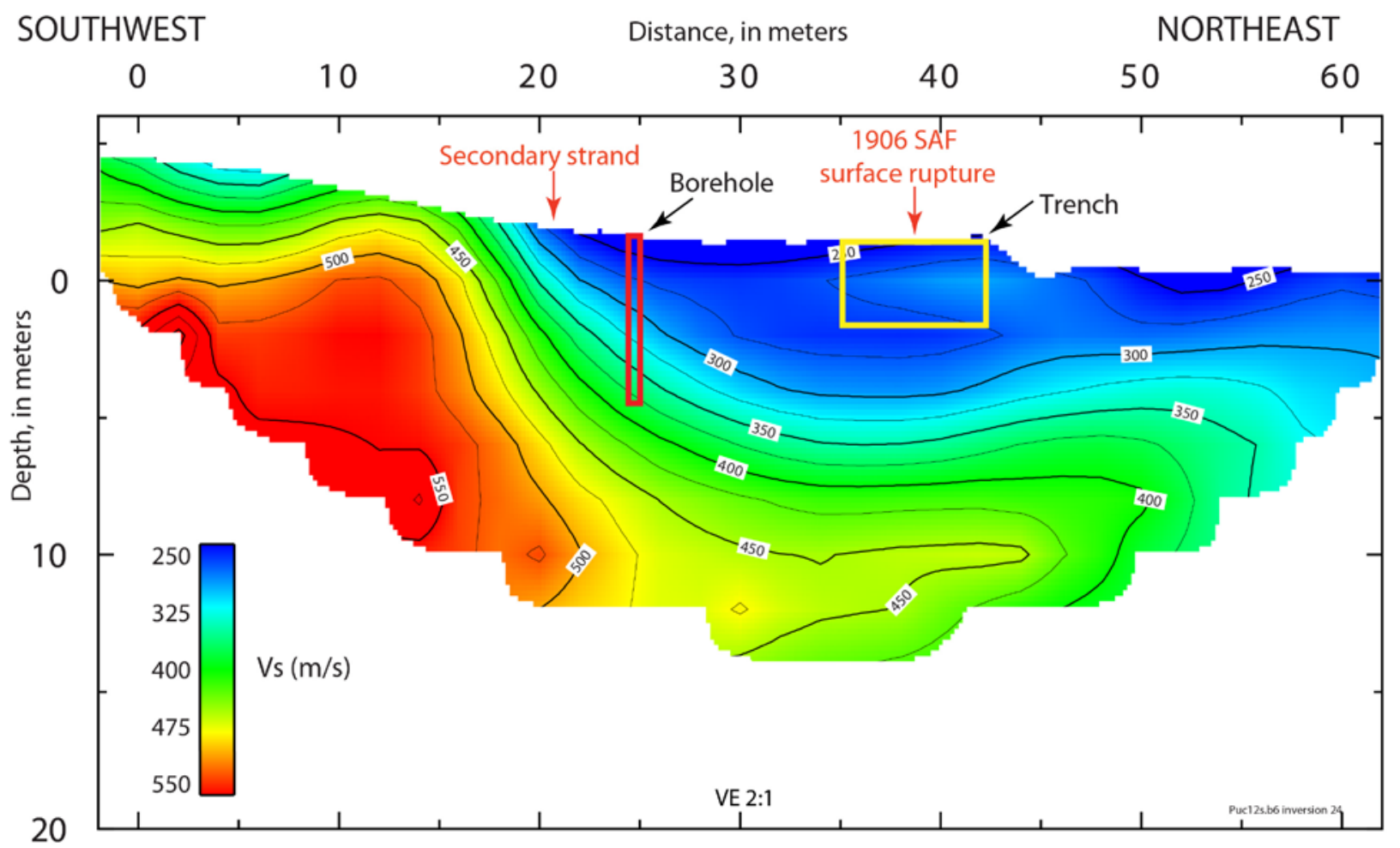

Figure 8. S-wave refraction tomography velocity model for the San Andreas Fault (SAF) profile. Red arrows point to locations of 1906 surface rupture at distance meter 38 and a possible secondary fault strand at distance meter 21. Red and yellow boxes show hand-augered borehole and trench locations, respectively, by Zachariasen and others (2011). 


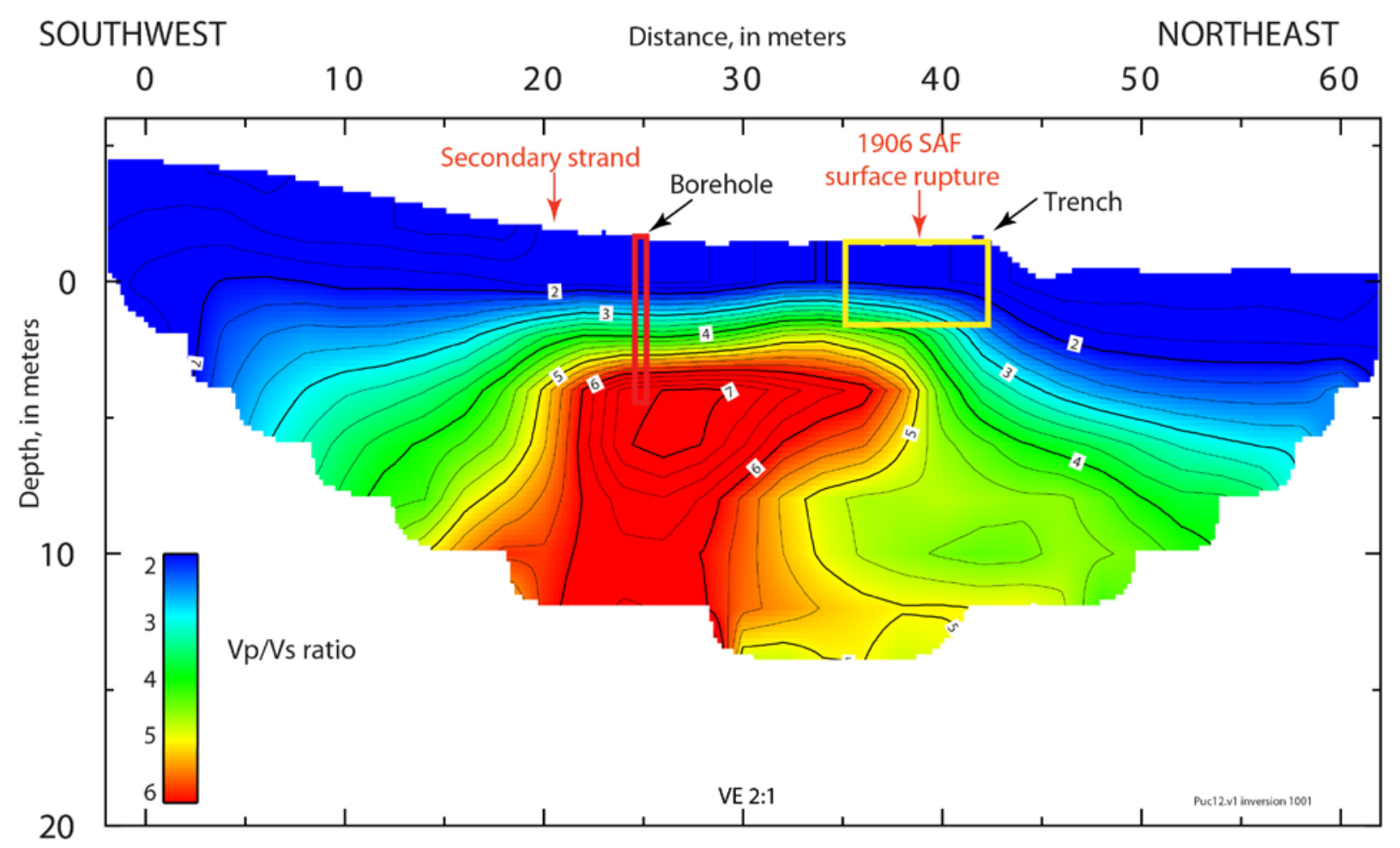

Figure 9. P-wave velocity/S-wave velocity (Vp/Vs) ratio image along our San Andreas Fault (SAF) profile. Relatively high $\mathrm{Vp} / \mathrm{Vs}$ ratios are interpreted to extend from near-surface main fault strand to maximum imaging depth. Red arrows point to locations of 1906 surface rupture at distance meter 38 and possible secondary fault strand at distance meter 21. Near-vertical zone of high $\mathrm{Vp} / \mathrm{Vs}$ ratios located at distance meter 27 is interpreted to be the main SAF zone. Red and yellow boxes show hand-augered borehole and trench locations, respectively, by Zachariasen and others (2011). 


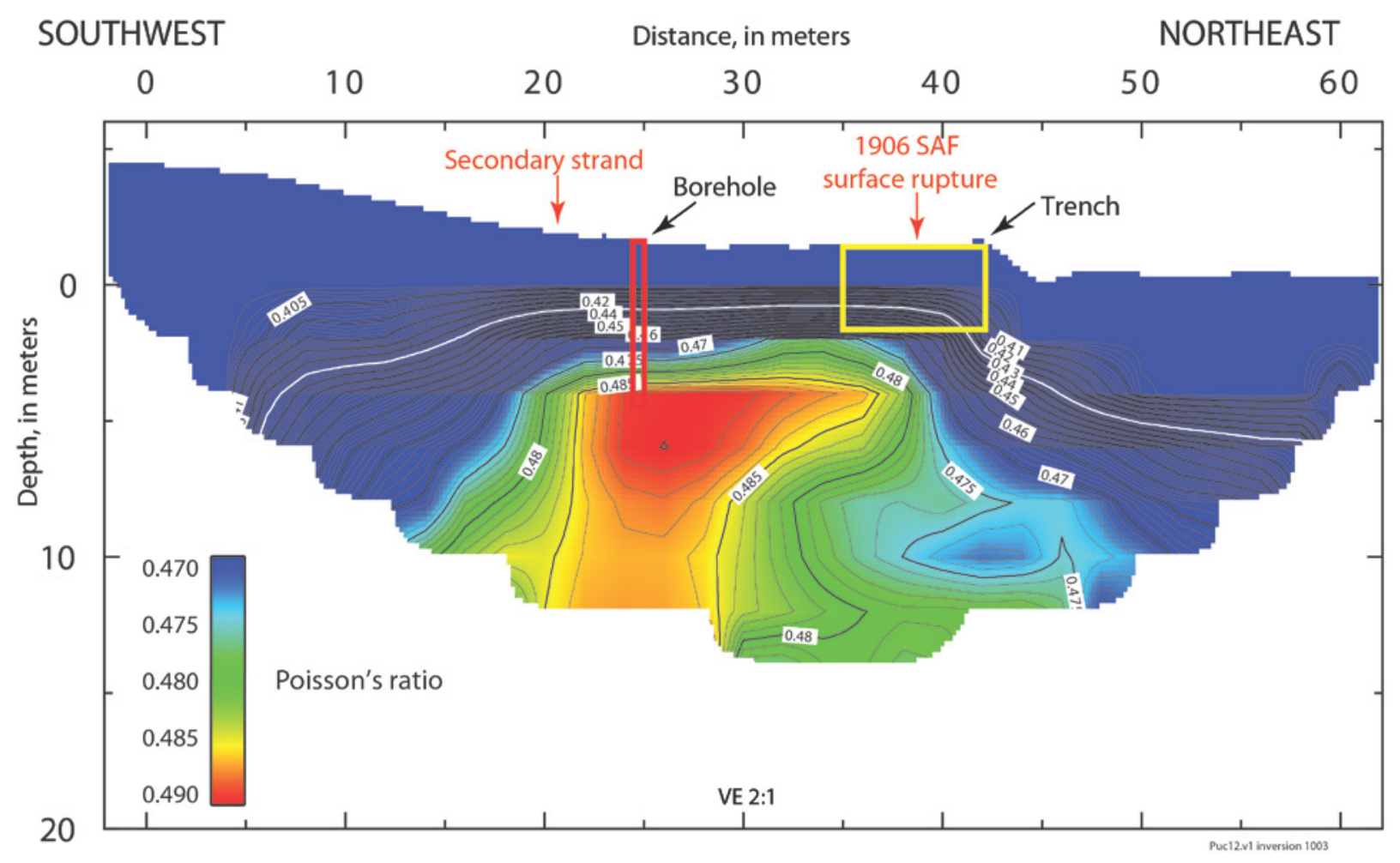

Figure 10. Poisson's ratio (PR) image along the San Andreas Fault (SAF) profile. Red arrows point to locations of 1906 surface rupture at distance meter 38 and possible secondary fault strand at distance meter 21. PR values exceeding 0.43 are interpreted as water-saturated. Highest PR values (0.49) coincide with our interpretation of main SAF fault strand. Red and yellow boxes show hand-augered borehole and trench locations, respectively, by Zachariasen and others (2011). 
A

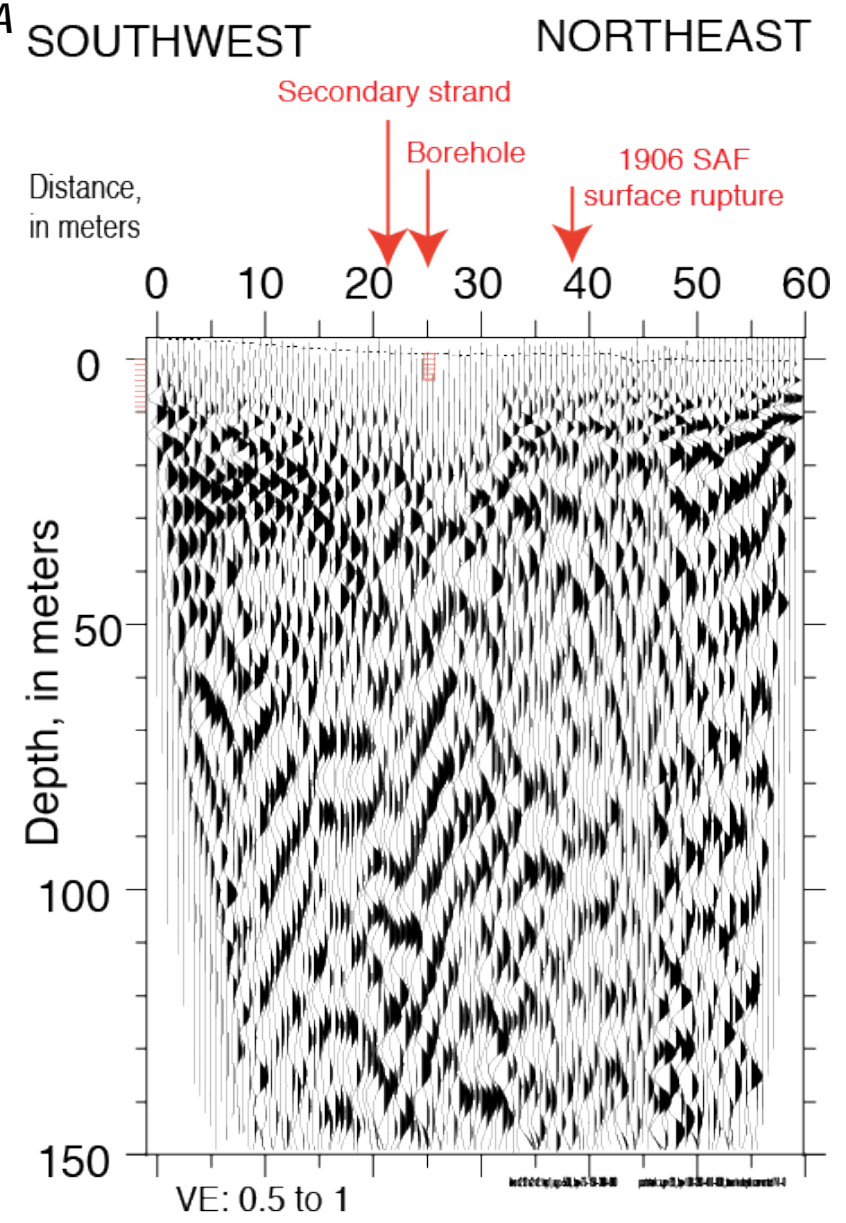

B SOUTHWEST NORTHEAST

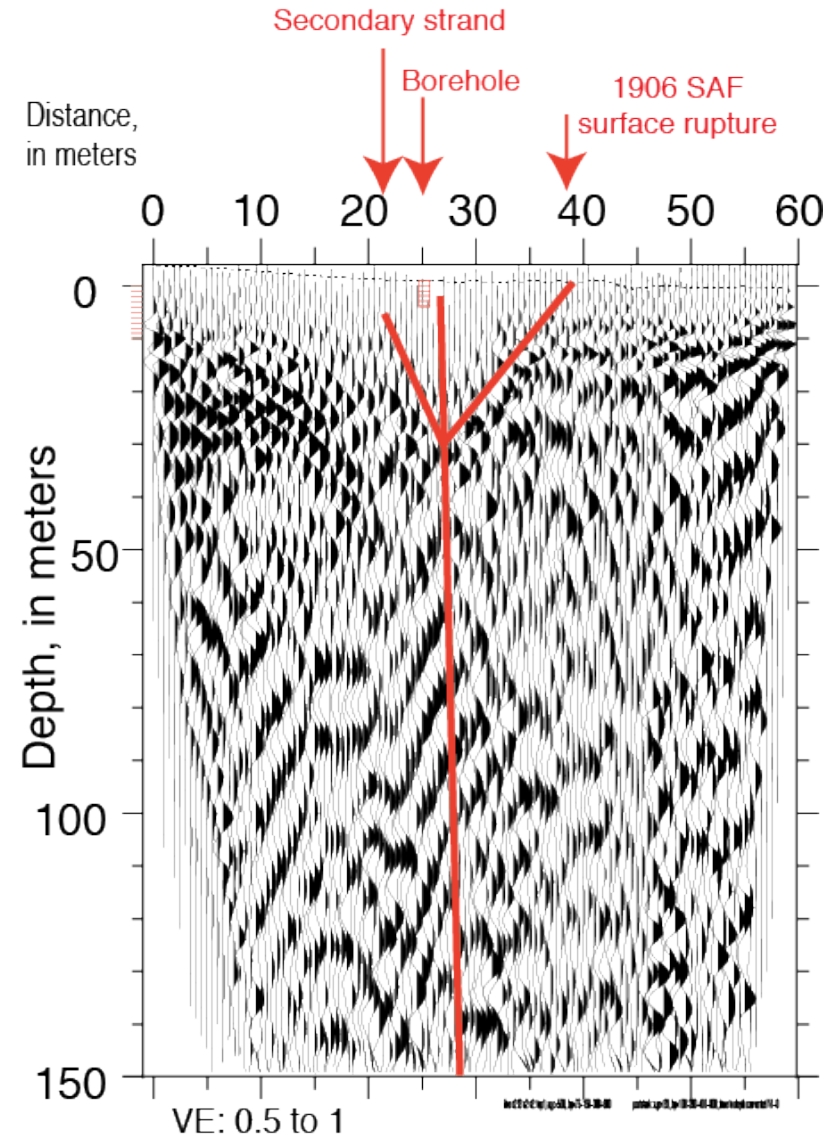

Figure 11. Stacked reflection images without $(A)$ and with $(B)$ fault geometry interpretation for our seismic profile. Red arrows point to possible locations of near-surface faults. 1906 surface rupture at distance meter 38 is interpreted to dip southwestward, and possible secondary strand at distance meter 21 is interpreted to dip northeastward; both faults join the main, near-vertical fault at less than $50 \mathrm{~m}$ depth. 
A

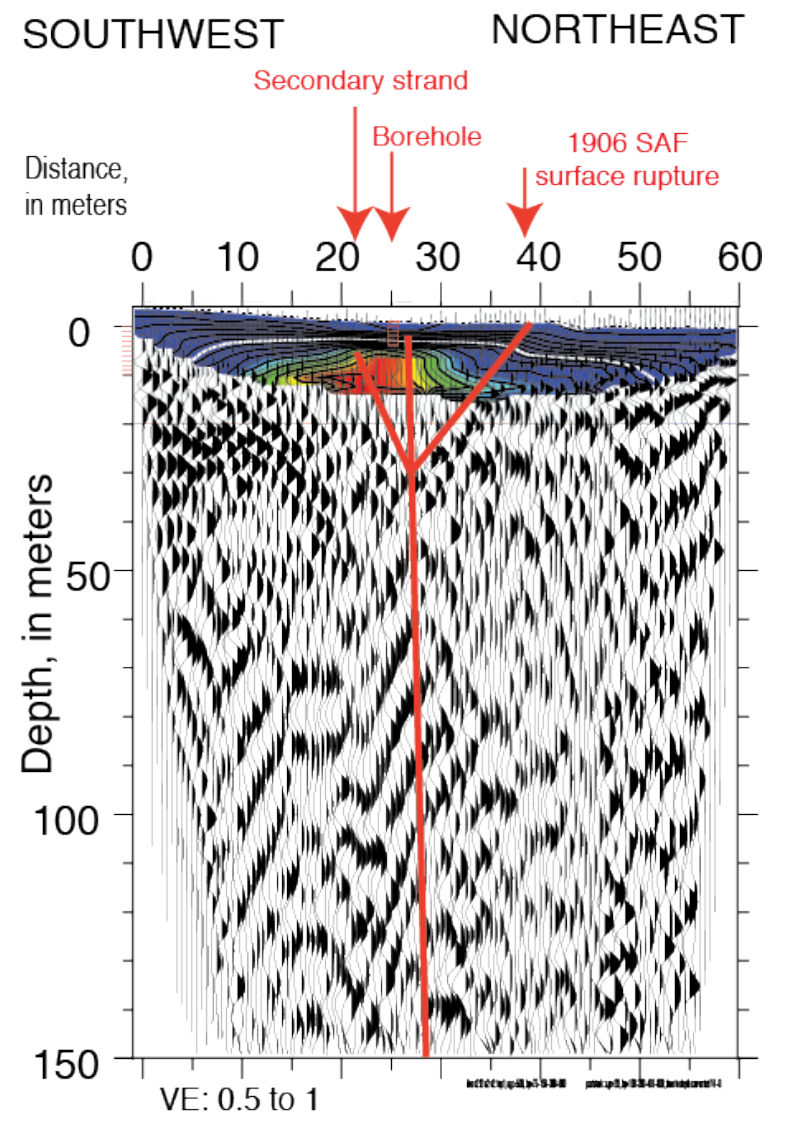

B

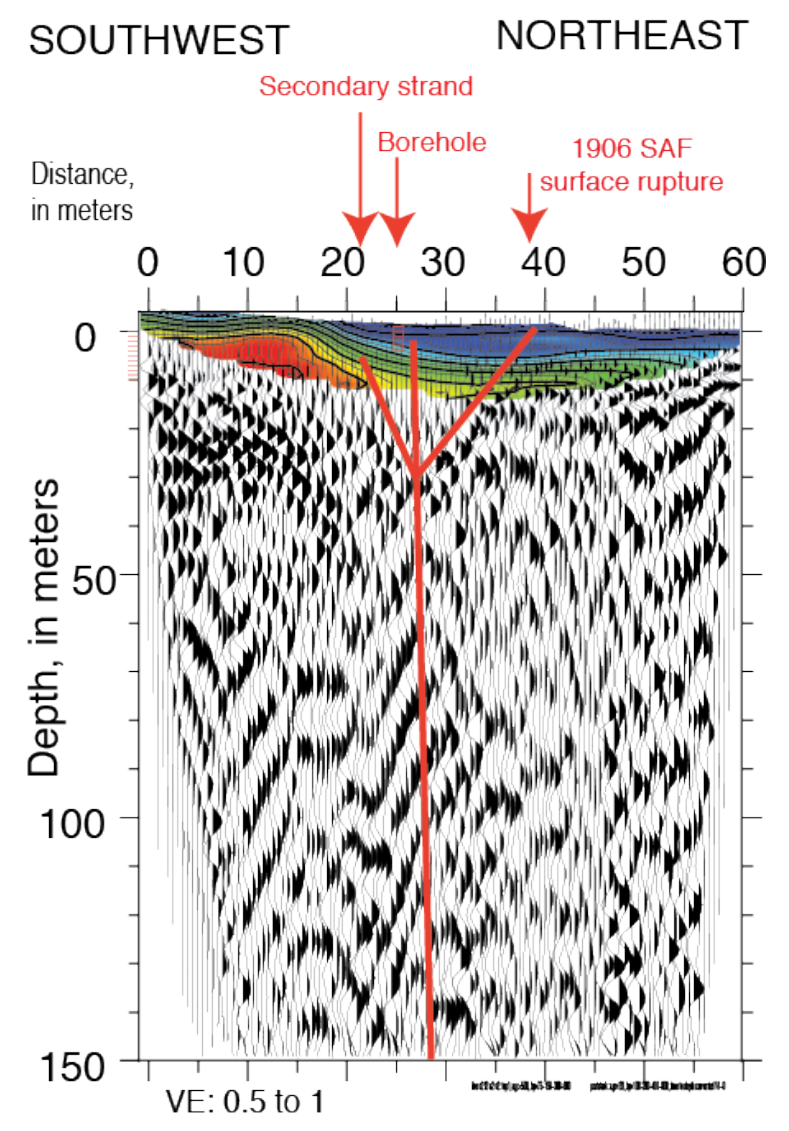

C

SOUTHWEST

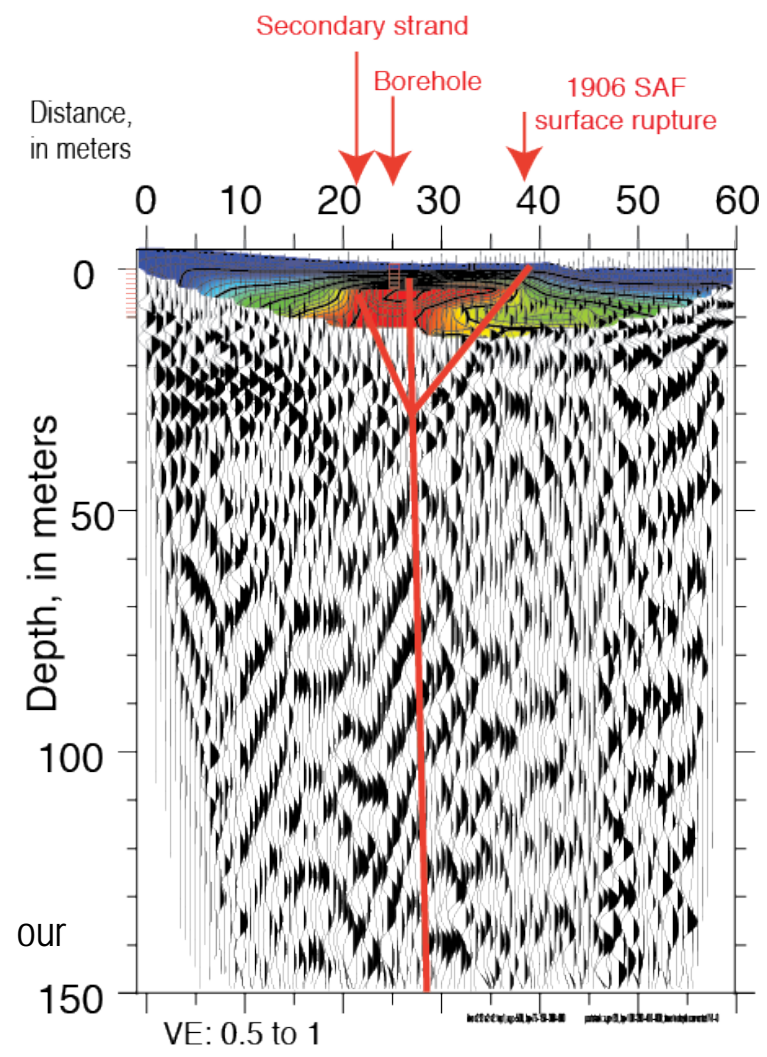

Figure 12. Stacked reflection images showing interpretations of near-surface San Andreas Fault (SAF) and secondary strand at study area with superimposed Vp model $(A)$, Vs model $(B)$, and P-wave velocity/S-wave velocity (Vp/Vs) ratios model $(C)$. 


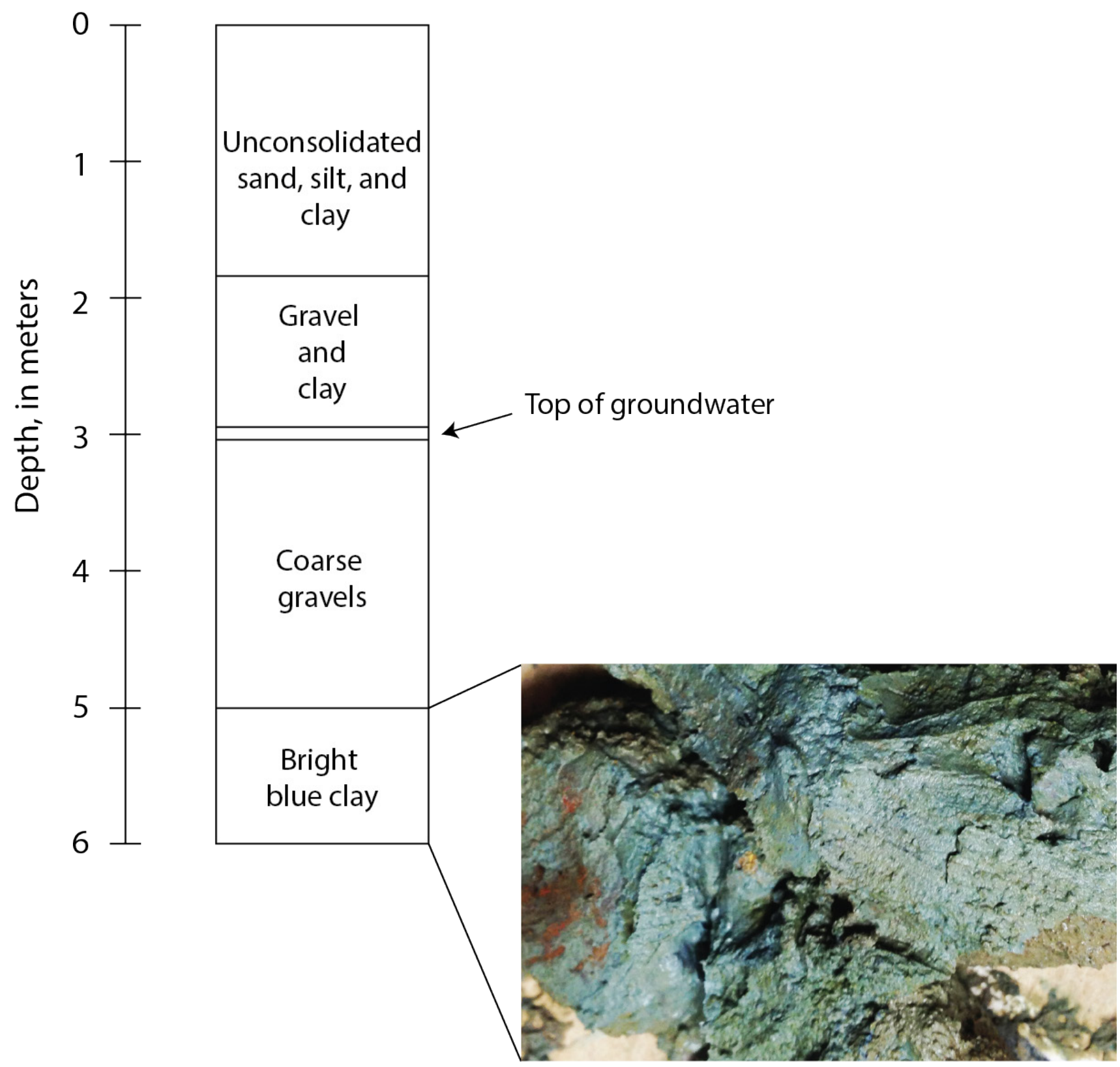

Figure 13. Diagram showing stratigraphic sequence from borehole located at distance meter 25 of our seismic profile. Photo shows blue clay found at bottom of the borehole. (USGS photograph by Carla Rosa, August 26, 2013) 